Chapman University

Chapman University Digital Commons

Mathematics, Physics, and Computer Science

Science and Technology Faculty Articles and

Faculty Articles and Research

Research

2011

\title{
Contrasting Aerosol Trends Over South Asia During the Last Decade Based on MODIS Observations
}

\author{
Dimitris G. Kaskaoutis \\ Sharda University, India \\ Shailesh Kumar Kharol \\ Dalhousie University, Canada \\ P. R. Sinha \\ Tata Institute of Fundamental Research, India \\ Ramesh P. Singh \\ Chapman University, rsingh@chapman.edu \\ K. V.S. Badarinath \\ National Remote Sensing Centre, Dept. of Space-Govt. of India \\ See next page for additional authors
}

Follow this and additional works at: http://digitalcommons.chapman.edu/scs_articles

Part of the Atmospheric Sciences Commons, and the Environmental Monitoring Commons

\section{Recommended Citation}

Kaskaoutis, D. G, Kharol, S.K., Sinha, P. R., Singh, R.P., Badarinath, K. V. S., Mehdi, W., and Sharma, M., 2011, Contrasting aerosol trends over South Asia during the last decade based on MODIS observations, Atmos. Meas. Tech. Discuss., 4, 5275-5323, 2011. doi: 10.5194/amtd-4-5275-2011

This Article is brought to you for free and open access by the Science and Technology Faculty Articles and Research at Chapman University Digital Commons. It has been accepted for inclusion in Mathematics, Physics, and Computer Science Faculty Articles and Research by an authorized administrator of Chapman University Digital Commons. For more information, please contact laughtin@chapman.edu. 


\section{Contrasting Aerosol Trends Over South Asia During the Last Decade Based on MODIS Observations}

\section{Comments}

This article was originally published in Atmospheric Measurement Techniques Discussions, volume 4, in 2011. DOI: 10.5194 /amtd-4-5275-2011

\section{Creative Commons License}

(c) (i)

This work is licensed under a Creative Commons Attribution 3.0 License.

Copyright

The authors

\section{Authors}

Dimitris G. Kaskaoutis, Shailesh Kumar Kharol, P. R. Sinha, Ramesh P. Singh, K. V. S. Badarinath, Waseem Mehdi, and Manish Sharma 
Atmos. Meas. Tech. Discuss., 4, 5275-5323, 2011

www.atmos-meas-tech-discuss.net/4/5275/2011/

Atmospheric doi:10.5194/amtd-4-5275-2011

\section{Contrasting aerosol trends over South Asia during the last decade based on MODIS observations}

D. G. Kaskaoutis ${ }^{1}$, S. K. Kharol ${ }^{2,3}$, P. R. Sinha ${ }^{4}$, R. P. Singh ${ }^{5}$, K. V. S. Badarinath ${ }^{2}$, W. Mehdi ${ }^{*}$, and M. Sharma ${ }^{1}$

${ }^{1}$ Research and Technology Development Centre, Sharda University, Greater Noida, NCR 201306, India

${ }^{2}$ Atmospheric Science Section, Oceanography Division, National Remote Sensing Centre, Dept. of Space-Govt. of India, Hyderabad 500 625, India

${ }^{3}$ Department of Physics and Atmospheric Science, Dalhousie University, Halifax, Canada

${ }^{4}$ National Balloon Facility, Tata Institute of Fundamental Research, Hyderabad 500 062, India

${ }^{5}$ School of Earth and Environmental Sciences, Schmid College of Science and Technology, Chapman University, Orange, CA 92866, USA

Contrasting aerosol trends over South

Asia

D. G. Kaskaoutis et al.

\section{Title Page}

Abstract

Introduction

Conclusions

Tables

References

Figures

14

4

Back

Close

\section{Full Screen / Esc}

Printer-friendly Version

Interactive Discussion 
*formerly at: Department of Civil Engineering, Indian Institute of Technology-Kanpur, Kanpur 201608, India

Received: 14 June 2011 - Accepted: 12 August 2011 - Published: 16 August 2011

Correspondence to: R. P. Singh (rsingh@ chapman.edu)

Published by Copernicus Publications on behalf of the European Geosciences Union.
AMTD

4, 5275-5323, 2011

\section{Contrasting aerosol trends over South \\ Asia \\ D. G. Kaskaoutis et al.}

Title Page

\section{Abstract}

Introduction

Conclusions

References

Tables

Figures

14

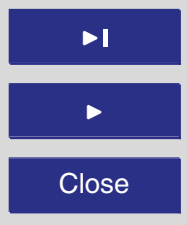

Back

Close

Full Screen / Esc

Printer-friendly Version

Interactive Discussion 


\section{Abstract}

Atmospheric aerosols over south Asia constitute a major environmental and climate issue. Thus, extensive land and cruise campaigns have been conducted over the area focusing on investigating the aerosol properties and climate implications. Except from the 5 ground-based instrumentation, several studies dealt with analyzing the aerosol properties from space, focusing mainly on the spatial distribution of the aerosol optical depth (AOD) and possible feedbacks of aerosols on the monsoon system. However, except from some works using ground-based instrumentation or satellite observations over a specific region, there is lack of studies dealing with monitoring of the aerosol trend over south Asia. The present work analyzes the variations and trends in aerosol load over south Asia using Terra-MODIS AOD 550 data in the period 2000-2009. Overall, an increasing trend of $10.17 \%$ in AOD is found over whole south Asia, which exhibits large spatio-temporal variation. More specifically, the $\mathrm{AOD}_{550}$ increasing trend is more pronounced in winter, and especially over northern India. The present study shows 15 an evidence of a decreasing $\mathrm{AOD}_{550}$ trend over the densely-populated Indo-Gangetic Plains (IGP) during the period April-September, which has never been reported before. This decreasing trend is not statistically significant and leads to an AOD change of -0.01 per year in June, when the dust activity is at its maximum. The AOD decrease seems to be attributed to weakness of dust activity in the northwest of India, closely associated with expansion of the vegetated areas and increase in precipitation over the Thar desert. Similarly, GOCART simulations over south Asia show a pronounced decreasing trend in dust AOD in accordance with MODIS. However, much more analysis and longer dataset are required for establishing this evidence.

\section{Introduction}

25 Atmospheric aerosols affect in many ways the global climatic system, i.e. by attenuating the solar radiation reaching the ground, modifying the solar spectrum, re-distributing
AMTD

4, 5275-5323, 2011

\section{Contrasting aerosol trends over South Asia}

D. G. Kaskaoutis et al.

\section{Title Page}

Abstract

Conclusions

References

Tables

Figures

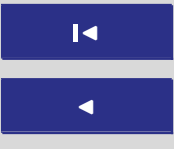

Back

Close

\section{Full Screen / Esc}

Printer-friendly Version

Interactive Discussion 
the earth-atmosphere energy budget and influencing cloud microphysics and hydrological cycle (IPCC, 2007). Although the aerosol optical properties have now been well known, large uncertainties still occur about the aerosol climate implications, and especially the aerosol indirect effect concerning the aerosol-cloud interactions, the changing 5 in cloud microphysical properties, the re-distribution of the cloudiness and the modification of the hydrological cycle (Rosenfeld et al., 2008). Despite the great progress that has been achieved in the current knowledge about atmospheric aerosols via the systematic ground-based and satellite observations, the uncertainties in their direct and indirect effects still exist, mainly due to the variety of the aerosol types, the changing 10 optical and physico-chemical properties, the influence of dynamic and synoptic meteorology and the mixing (internal and external) processes in the atmosphere (Satheesh and Moorthy, 2005).

Atmospheric aerosols have been recognized to constitute a vital parameter in climate change studies over south Asia that examine fluctuations in atmospheric temperature 15 (e.g. Lau et al., 2006; Gautam et al., 2009a), radiative forcing (e.g. Ramachandran and Kedia, 2010; Satheesh et al., 2010) snow and ice-cover (e.g. Prasad and Singh, 2007), precipitation re-distribution (e.g. Prasad et al., 2007; Sarkar et al., 2007), frequency and intensity of tropical cyclones (e.g. Badarinath et al., 2009) and desertification (e.g. Prospero et al., 2002). Different types of aerosol are found over the Indian sub-continent, i.e. anthropogenic aerosols from the urban centers, biomass burning from seasonal forest fires or crop residue burning especially in the north-western part of India (Vadrevu et al., 2011), desert dust produced in the Thar desert or transported from the Arabia peninsula and marine aerosols from the surrounding oceans during the southwest summer monsoon (Dey et al., 2004; Ganguly et al., 2006a; Kaskaoutis use and seasonally-changed air masses, the aerosol load, optical properties and their climate implications present large variations over India, both spatially and temporally (Lawrence and Lelieveld, 2010).

\section{AMTD}

4, 5275-5323, 2011

\section{Contrasting aerosol trends over South Asia}

D. G. Kaskaoutis et al.

\section{Title Page}

Abstract Introduction

Conclusions

Tables

References

Figures

14

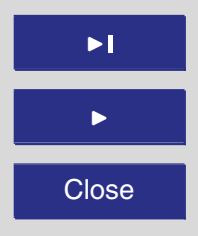

Back

Close

\section{Full Screen / Esc}

Printer-friendly Version

Interactive Discussion 
With the increase in population, urbanization, industrialization and demands for energy, the aerosol load in south Asia is gradually increasing having significant impact on continuation of solar dimming (Ohmura, 2009; Badarinath et al., 2010). Both groundbased measurements and satellite observations agree to an overall increase in AOD 5 over the area (e.g. Massie et al., 2004; Sagar et al., 2006; Prasad and Singh 2007; Ramachandran and Cherian, 2008; Kharol et al., 2011). The increasing aerosol emissions, mainly from anthropogenic activities, are responsible for the presence of the atmospheric brown clouds (Ramanathan et al., 2005, 2007), which have significant climate implications in view of heating the middle and upper troposphere (Menon et 10 al., 2002; Gautam et al., 2010). Sarkar et al. (2006) reported statistically significant increasing trends in Al over all major cities located in northern India during the period 1982-1993, while over the same region the aerosol radiative forcing (ARF) at the surface was much more negative from that observed over central and south India due to larger AOD and higher concentrations of absorbing aerosols. Prasad and Singh (2007) 15 analyzed the AOD trends from MODIS, MISR and AERONET (at Kanpur) over five urban locations in northern India and found increasing trends in AOD on annual basis during the period 2000-2005. Ramachandran and Cherian (2008) analyzed the MODIS-AOD variations and trends over 35 locations spread uniformly over India and reported increasing trends in the yearly-mean AODs over all sites during the period 2001-2005. However, in the aforementioned studies there is lack of analysis of the monthly and/or seasonal trends of AOD over the different areas. More recently, Dey and Di Girolamo (2010) using MISR data over south Asia analyzed the seasonal differences in AOD and in anthropogenic and natural aerosol contributions, while Kharol et al. (2011) reported statistically significant aerosol increase ( 20-34\%) over Hyderabad (2002-2008) detected both by ground based measurements and MODIS observations; however, the rainy monsoon season was not included in the analysis. Kishcha et al. (2011) found that the largest AOD increase is observed over the most densely populated areas over India, highlighting a 2\% increase in AOD for regions with population density above 100 persons per $\mathrm{km}^{2}$.

\section{AMTD}

4, 5275-5323, 2011

\section{Contrasting aerosol trends over South Asia}

D. G. Kaskaoutis et al.

\section{Title Page}

Abstract Introduction

Conclusions

Tables

References

Figures

14

$\Delta \mathbf{I}$

4

Back

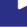

Close

\section{Full Screen / Esc}

Printer-friendly Version

Interactive Discussion

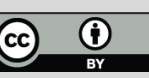


A detailed analysis of spatial distribution of the AOD trends over south Asia on monthly, or even on seasonal basis has not been carried out. Such studies are required to understand the nature of aerosols, monthly and seasonal dynamics of aerosols and their impact on the climate change. The present study aims to report the results of 5 the spatial distribution of AOD trends over south Asia during the last decade (20002009), focusing mainly on specific regions, i.e. Arabian Sea (AS), Bay of Bengal (BoB), Northern Indian Ocean (NIO) and Indo-Gangetic Plains (IGP). The analysis is made on monthly basis basically using Terra-MODIS data and emphasizing further on AOD variations and trends over IGP, where a decreasing trend in AOD is found during late 10 pre-monsoon and monsoon seasons. This decreasing trend is associated with land use/land cover changes over Thar desert, variations in precipitation and a general attenuation in the dust activity over south Asia as detected from GOCART simulations.

\section{Data set and study regions}

The main dataset used in the present study consists of Terra-MODIS AOD 550 observa15 data used are from collection $5(\mathrm{CO05})$ Level $3\left(1^{\circ} \times 1^{\circ}\right)$ following the dark-target approach for aerosol retrievals over vegetated and oceanic surfaces with lack of data over the deserts (Levy et al., 2007). The spatio-temporal resolution of the dataset used is satisfactory for the scope of the study which is the climatology and variation of AOD

\section{over south Asia during the last decade. Numerous studies have been conducted over} the globe aiming for validation of the MODIS data with ground-based sun photometers and other satellite sensors; satisfactory agreement between MODIS and AERONET AODs over Kanpur, India was found in several earlier publications (Jethva et al., 2007; Prasad and Singh, 2007; Ramachandran, 2007), thus rendering the satellite observa-

\section{AMTD}

4, 5275-5323, 2011

\section{Contrasting aerosol trends over South Asia}

D. G. Kaskaoutis et al.

\section{Title Page}

Abstract

Introduction

Conclusions

Tables

References

Figures

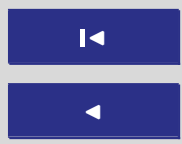

Back

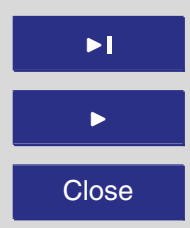

Full Screen / Esc

Printer-friendly Version

Interactive Discussion 
The Indian sub-continent exhibits a diverse topography with large variability in vegetation cover, ranging from the desert regions in the northwest to arid areas in the central-south and to dense vegetated areas along the southwestern coast and the northeastern part. More details concerning the climatology, land use, industrialization 5 and aerosol emissions for different areas in India can be found elsewhere (Ramachandran and Cherian, 2008; Lawrence and Lelieveld, 2010). As far as the present analysis is concerned, the study region is defined by the co-ordinates $0-30^{\circ} \mathrm{N}$ and $58-95^{\circ} \mathrm{E}$, including the Indian sub-continent (except the northernmost part), the AS, BoB and NIO. Since the analysis focuses on 4 specific regions with different weather conditions, 10 aerosol characteristics and influences are discussed region wise.

\subsection{Arabian Sea}

In the present study, the AS is defined by the oceanic pixels above $8^{\circ} \mathrm{N}$ and west $67^{\circ} \mathrm{E}$ bounded by the Arabian peninsula in the northwest, Iran and Pakistan in the north and the western Indian coast in the east. The south-to-north movement of the Inter-Tropical 15 Convergence Zone (ITCZ) mainly controls the meteorological and weather conditions over the area (Krishnamurthi et al., 1998). The AS is strong influenced by the local monsoon system, especially in summer when strong southwestern marine winds in the lower troposphere blow towards Indian mainland, while in the middle and upper troposphere westerlies bring large amounts of dust over the AS. The aerosol field over 20 the area has been extensively investigated during several cruise campaigns (e.g. Indian Ocean Experiment, INDOEX; Arabian Sea Monsoon Experiment, ARMEX; Integration Campaign for Aerosols, gases and Radiation Budget, ICARB) which focused on regionspecific characterization of the aerosol properties. Results from these campaigns have shown large amounts of wind-blown dust and anthropogenically-produced aerosols 2005; Kalapureddy et al., 2009; Kaskaoutis et al., 2010). Radiative forcing studies (Satheesh et al., 2006) have shown large attenuation of solar radiation in the surface and a negative (cooling effect) in the top of the atmosphere.

\section{AMTD}

4, 5275-5323, 2011

\section{Contrasting aerosol trends over South Asia}

D. G. Kaskaoutis et al.

\section{Title Page}

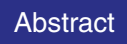

Introduction

Conclusions

Tables

References

Figures

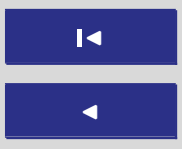

$>$ I

Back

Close

\section{Full Screen / Esc}

Printer-friendly Version

Interactive Discussion
$>$

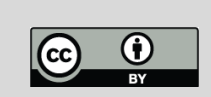




\subsection{Bay of Bengal}

The $\mathrm{BoB}$ has a unique weather pattern in terms of the Indian monsoon, being also under the influence of tropical cyclones (Badarinath et al., 2009). The region is surrounded by densely populated and industrialized regions from north, west and east,

5 BoB provides an excellent environment for investigation of marine and continental aerosols, since pristine air masses from southern Indian Ocean and polluted air from the Indian sub-continent meet. The continental aerosols transported over BoB are of various origins (sea-salt production, dust particles, fossil-fuel combustion, biomass burning) and chemical compositions (e.g. Kumar et al., 2010), also present variable 10 optical properties in spatial and temporal domains (e.g. Kaskaoutis et al., 2011). The western and northern BoB are strongly affected by the Indian landmass, while the eastern part is under the influence of the southeast Asia (Sinha et al., 2011). Some short term cruises (Ramachandran and Jayaraman, 2003; Vinoj et al., 2004; Ganguly et al., 2005) have been carried out in BoB focusing mainly in aerosols and pollutants in 15 coastal waters, until ICARB (Moorthy et al., 2008) and W-ICARB (Raghavendra Kumar et al., 2011) explored the region in more detail during pre-monsoon and winter seasons, respectively. In the following, the BoB is defined as the oceanic area east from $80^{\circ} \mathrm{E}$ and north from $8^{\circ} \mathrm{N}$.

\subsection{Northern Indian Ocean}

20 The aerosols over the NIO have initially been investigated in the framework of INDOEX (Ramanathan et al., 2001; Satheesh et al., 2002) and in some cruises starting from southern India to the premises of Antarctica (Vinoj et al., 2007). More recently, ICARB and W-ICARB campaigns also focused on aerosol field in parts of $\mathrm{NIO}$, around $3^{\circ} \mathrm{N}$. The oceanic region is characterized by more transparent atmospheric conditions, where the ITCZ plays a major role in long-range aerosol transport from Indian mainland. Although, the AOD is, in general, below 0.25, a large anthropogenic component was found over the northern parts of the NIO (Nair et al., 2010). In the present study, we have considered the $\mathrm{NIO}$ as the whole oceanic area south of $8^{\circ} \mathrm{N}$.

\section{AMTD}

4, 5275-5323, 2011

\section{Contrasting aerosol trends over South Asia}

D. G. Kaskaoutis et al.

\section{Title Page}

Abstract

Introduction

Conclusions

References

Tables

Figures

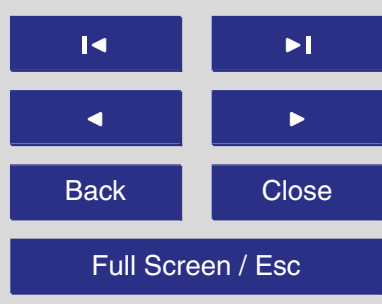

Printer-friendly Version

Interactive Discussion 


\subsection{Indo-Gangetic Plains}

The northern part of India is crossed by the Ganges river; on the north side the region is surrounded by the towering Himalaya, the Thar desert in the west, Vindhayan hill in the south and the Bay of Bengal in the east. This area is known as Indo-Gangetic 5 Plains (IGP) accounting for $21 \%$ of the land area of the Indian sub-continent and holding nearly $40 \%$ of the total population (Badarinath et al., 2011). During the winter season, the area suffers from severe fog and haze conditions causing pollution smog environment, which was first time observed by the ADEOS POLDER satellite (Goloub et al., 2001). Numerous studies during the last decade examined the aerosol load 10 and optical properties over the IGP focusing mainly in the winter season, due to foggy conditions and large black carbon (BC) concentrations, and pre-monsoon and early monsoon due to frequent dust outbreaks from the Thar desert (Dey et al., 2004; Singh et al., 2004; Jethva et al., 2005; Ganguly et al., 2006b; Ramachandran et al., 2006; Prasad et al., 2004, 2006, 2007; Das et al., 2008; Gautam et al., 2009a, b). Several

15 industries and thermal power plants are located in the IGP contributing to significant aerosol and pollution emissions (Reddy and Venkataraman, 2002; Prasad et al., 2006; Singh, 2011). We have considered IGP area bounded by $21.5-30^{\circ} \mathrm{N}$ and $74-91^{\circ} \mathrm{E}$, excluding the pixels over Nepal and Himalaya in the analysis.

\section{Results and discussion}

20 3.1 Seasonal variation of the $\mathrm{AOD}_{550}$ over south Asia

In this section a description regarding the aerosol field over south Asia based on MODIS observations during the period 2000-2009 is given. Figure 1 shows the monthly mean $\mathrm{AOD}_{550}$ spatial distribution over south Asia during the last decade for four representative months. The AOD seasonality, despite some differences observed from region-to-region, in general, exhibits an annual pattern of lower values during post-monsoon and winter and higher during pre-monsoon and monsoon, depending on the location. All studies conducted over the area show larger BC concentrations and

AMTD

4, 5275-5323, 2011

\section{Contrasting aerosol trends over South Asia}

D. G. Kaskaoutis et al.

\section{Title Page}

Abstract Introduction

Conclusions

Tables

References

Figures

14

$>1$

4

Back

Close

\section{Full Screen / Esc}

Printer-friendly Version

Interactive Discussion

$>$ 
the presence of anthropogenic aerosols during winter season. Anthropogenic aerosols are the dominant type over south Asia since they contribute about $70-80 \%$ to the total AOD (Chung et al., 2005), being also the dominant type both over urban locations (Kaskaoutis et al., 2009) and downwind oceanic areas (Ramachandran et al., 2004). 5 In rural and agricultural areas the fine-mode aerosols mainly originate from burning of bio-fuels, while in urban areas from fossil-fuel combustion.

In the month of January, during peak winter season, a narrow belt of very large AOD is observed along the IGP, mainly over its eastern part, also influencing the western and the northern BoB. Pronounced continental influence is seen along the coastal AS, 10 while northern $A S, N I O$ and southern India exhibit $A D_{550}$ values below 0.2. In April the AOD is gradually increasing over continental India and adjoining oceanic areas, with an evidence of decrease in the eastern IGP. From April onwards the dust activity over the northwestern arid regions starts (note the large AOD over Pakistan) spreading dust aerosols over the northern and central parts of India (e.g. Dey et al., 2004; El-

15 Askary et al., 2006); the dust activity is strengthened and shifts towards north AS during the monsoon season, while the Indian landmass is under the influence of oceanic air masses. Long-range dust transport from the Arabian peninsula and the Middle East in the middle and upper troposphere (up to $5 \mathrm{~km}$, Gautam et al., 2010) consist a significant contribution to the high AOD over central-north AS and western India in July relative to the other months. In October, the dust activity disappears and the AOD range is observed similar to the range observed during January and April. The main characteristic is the increased AOD over the northwestern IGP in the month of October associated with crop residue burning (Sharma et al., 2010). However, apart from the large aerosol emissions produced over Indian mainland, trans-boundary aerosol and 25 pollution transport from southeast Asia and Middle East also affects the study region. More detailed analysis of the seasonal mean AOD spatial distribution over the area is given by Dey and Di Girolamo (2010) using MISR data, which follows the pattern of MODIS-AOD spatial distribution.

\section{AMTD}

4, 5275-5323, 2011

\section{Contrasting aerosol trends over South Asia}

D. G. Kaskaoutis et al.

\section{Title Page}

Abstract Introduction

Conclusions

Tables

References

Figures

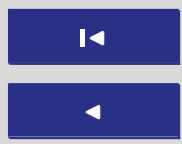

$\Delta$

Back

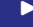

Close

\section{Full Screen / Esc}

Printer-friendly Version

Interactive Discussion 
Figure 2 presents the annual variation of $A D_{550}$ in box chart view over the four distinct areas in south Asia revealing, except from the monthly mean and median values, the $25 \%$ and $75 \%$ percentiles as well as the spread of the $A O D_{550}$ distribution. AS presents a pronounced annual variation in $\mathrm{AOD}_{550}$ with increased values during June-

5 August. Although the spatial and temporal variability is very large during the monsoon, in post-monsoon and winter seasons, the $A \mathrm{DD}_{550}$ is about 0.22 representing a rather homogeneous atmosphere. The mean $A D_{550}(0.35 \pm 0.17)$ is larger than that found over $\mathrm{BoB}(0.30 \pm 0.08)$, although ICARB and other previous cruise campaigns reported larger AODs over BoB compared to AS. The larger AOD over AS is attributed to the 10 very high values during the monsoon season, since the area is under the influence of the arid regions in the west and north, whereas such an influence is very limited over BoB. However, during the winter season and March-April when the W-ICARB and ICARB campaigns took place, the MODIS-AOD ${ }_{550}$ over $\mathrm{BoB}$ is higher. There is also a shift in the maximum monthly $A_{O D} D_{550}$ over $B o B$ observed during May-June, while the 15 spread of the data and the annual variation are significantly lower than those over AS. The most transparent and homogeneous area is $\mathrm{NIO}$ (mean $\mathrm{AOD}_{550}=0.18 \pm 0.03$ ), also presenting the lowest annual variability. The latter is mainly controlled by longrange aerosol transport, i.e. dust particles from the west in May-July and continental outflows in the winter, when the anthropogenic contribution over NIO was found to be $80 \pm 10 \%$ (Ramanathan et al., 2001). The large amount of anthropogenic aerosols during the winter season, in combination with dust aerosols during April-July and cropresidue burning in post-monsoon, cause high $A O D_{550}$ values $(0.50 \pm 0.15)$ throughout the year over IGP. Both dust and biomass burning have a pronounced signal in Al over the area, especially in the dry season when their atmospheric lifetime is larger (Habib et al., 2006). Aerosols over IGP undergo a pronounced annual variation in both load and type with very large AODs (mean 0.7) in May-July (dust aerosols mixed with anthropogenic ones) and moderate-to-high AOD ( 0.4-0.45) during the winter season (anthropogenic aerosols and BC).
AMTD

4, 5275-5323, 2011

\section{Contrasting aerosol trends over South Asia}

D. G. Kaskaoutis et al.

\section{Title Page}

Abstract Introduction

Conclusions

Tables

References

Figures

14

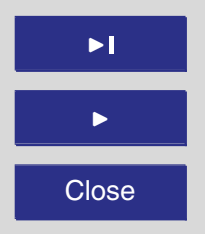

Back

Close

\section{Full Screen / Esc}

Printer-friendly Version

Interactive Discussion 
The IGP has been well recognized to constitute the main anthropogenic-pollution aerosol source region in India (Di Girolamo et al., 2004; Eck et al., 2010; Lawrence and Lelieveld, 2010; Giles et al., 2011). Under favorable wind conditions the aerosols are spreading over the whole Indian mainland, surrounding oceans and the foothills 5 of the Himalaya. To this respect, Fig. 3 shows the correlation of the monthly-mean area-averaged $\mathrm{AOD}_{550}$ between IGP and the three oceanic regions. The correlation is statistically significant regarding the co-variance between AODs over IGP and BoB, since the latter is in the downwind region of aerosol outflow especially in winter and early pre-monsoon (Nair et al., 2009; Moorthy et al., 2010). It should be noted that o considering as $\mathrm{BoB}$ the oceanic region north of $15^{\circ}$ the $R^{2}$ value goes up to 0.75 . On the other hand, pronounced positive correlation is shown between IGP and AS, but with lower coefficient of determination. Note that in some months (monsoon period) the AODs over AS are larger, directly influenced by dust outflow from Arabia and Middle East and not from aerosols coming from IGP; AS is in the downwind region of 15 western IGP mainly in post-monsoon and winter. Finally, the aerosol field over NIO does not seem to be influenced by IGP aerosols on monthly basis. The slight positive correlation is attributed to the co-variance of the annual AOD pattern (Fig. 2), but the larger AODs over NIO in monsoon are mainly controlled by marine particles and air masses coming from the west. However, for establishing the IGP effect in controlling the aerosol variations over various locations in south Asia the analysis has to be carried out on daily basis examining the air-mass trajectories, over Himalaya (Gobbi et al., 2010), northeastern India (Pathak et al., 2010; Gogoi et al., 2011), BoB (Moorthy et al., 2003) and AS (Vinoj et al., 2010).

\subsection{Temporal variation and trend of $A O D_{550}$ over south Asia in the last decade}

25 In this section the decadal (2000-2009) changes in MODIS-AOD 550 values over south Asia are examined. The AOD variation is quantified via the slope values of the linear regressions and the (\%) differences in AOD on monthly basis. The spatial distribution $\left(1^{\circ} \times 1^{\circ}\right.$ resolution) of the slope values is shown in Fig. 4 . During the winter months

\section{AMTD}

4, 5275-5323, 2011

\section{Contrasting aerosol trends over South Asia}

D. G. Kaskaoutis et al.

\section{Title Page}

Abstract Introduction

Conclusions

Tables

References

Figures

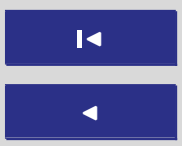

$\Delta$

Back

Close

\section{Full Screen / Esc}

Printer-friendly Version

Interactive Discussion
$>$

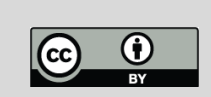


(December to February) a pronounced increasing trend in $\mathrm{AOD}_{550}$ is observed over south Asia, especially over the Indian mainland and IGP, while over NIO and the southern parts of BoB and AS the trend is rather neutral. The increasing aerosol load over northern India seems to affect the northern BoB and eastern coastal AS due to in5 creased outflows. The overall increasing trend in the region is reported by many as cited in the introduction. On the other hand, a slight statistically insignificant decreasing trend in $\mathrm{AOD}_{550}$ (-0.01 per year, or even less) is observed over southwestern India in January, which must be examined from ground-based instruments for defining its reliability.

10 In March the trend starts changing; either similar or even slight by declining AOD trends are observed over northwestern India, NIO and southern BoB. On the other hand, the increasing AOD trend remains over eastern IGP, Bangladesh and northern $\mathrm{BoB}$. In April, the situation is significantly changed with the AS exhibiting on increasing trend, while central and northern India constant or declining trend. A reliable explana-

tion about this feature is rather difficult to be established taking also into account the reverse situation in May (neutral or slight decreasing trend over AS and increasing over $\mathrm{BoB}$ ). Thus, to attribute the increase in AOD over AS in April to enhancement in dust activity over the Arabia peninsula may be not the real scenario, since in May the AOD trend is negative over the same region. Similarly, the increasing AOD over BoB in May cannot be attributed to increased emissions from IGP (the results show decreasing trends), and changes in other aerosol sources must be examined, i.e. biomass burning in southeast Asia. Examining the yearly variation of the area-averaged values (not shown), we found that over AS in April the mean $A O D_{550}$ was nearly steady to $\sim 0.275$ during the period 2000-2006, while in 2007-2009 the AOD $_{550}$ increased to 0.35-0.4, thus leading to the increasing trend. Similarly, the pronounced increasing AOD trend over the whole BoB in May is controlled by the increased area-averaged value (0.6) in May 2008 against the mean of 0.4 for this month during the period 2000-2009. This suggests that the spatial distribution of the AOD trends are strongly influenced by yearly variations and, therefore, the results (Fig. 4) can be assumed rather qualitative and not
AMTD

4, 5275-5323, 2011

\section{Contrasting aerosol trends over South Asia}

D. G. Kaskaoutis et al.

\section{Title Page}

Abstract

\section{Introduction}

Conclusions

Tables

References

Figures

14

$\Delta$

4

Back

\section{Full Screen / Esc}

Printer-friendly Version

Interactive Discussion 
quantitative. On the other hand, a longer period must be considered for such analysis and the MODIS retrievals have to be compared with ground-based measurements in order to examine any agreement or disagreement in the spatial distributions presented here.

5 In monsoon months (June-September) the spatial distribution of the slope presents large deviations from region-to-region (for areas above $15^{\circ} \mathrm{N}$ ), and it is difficult to conclude about the trend. Furthermore, the AOD trends are much more intense than the rest of the year. This may be attributed to the extensive cloud cover in this season reducing the number of valid MODIS observations and leading to sharper spatio-temporal 10 variation. Quite interesting is the pronounced increasing AOD trend over AS in June and the decreasing one over coastal western India. This can be partly explained by large variations in cloudiness and precipitation over western India, where the rainfall monsoon season starts in the beginning of June (Kishcha et al., 2011). Northwestern India is affected by monsoon by the end of June, and as a consequence, the MODIS re15 trievals in July and August are limited due to extensive cloudiness. So, there is possibility of lack of data in some years over specific pixels in this area leading to the observed complicated pattern as regards the AOD trends. Similar feature is shown over central India and the northern BoB attributed to the same reason. The observed trends, even over specific locations, are difficult to be verified using ground-based sun-photometers due to extensive cloudiness in this season, suggesting the use of longer-term satellite observations as absolutely necessary. Nevertheless, an overall decreasing trend in AOD is observed over IGP in the monsoon months.

In post-monsoon months (October-November), the spatial distribution shows neutral-to-increasing AOD trends over the oceanic regions, which are larger over the coastal BoB and the AS in October. The slightly decreasing AOD trend over IGP in October shifts to increasing in northwestern parts of this region in November, probably due to increased biomass-burning activities. An indication for the latter is the increasing $\mathrm{CO}$ and $\mathrm{NO}_{2}$ emissions over Punjab state, an agricultural area in northwestern India, during the last years (not shown).

\section{AMTD}

4, 5275-5323, 2011

\section{Contrasting aerosol trends over South Asia}

D. G. Kaskaoutis et al.

\section{Title Page}

Abstract Introduction

Conclusions

Tables

References

Figures

14

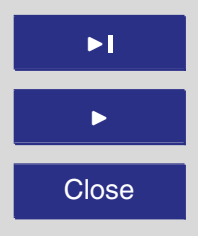

Back

Close

\section{Full Screen / Esc}

Printer-friendly Version

Interactive Discussion

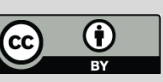


Figure $5 \mathrm{a}$ shows the monthly mean variation and trends of the area-averaged $A O D_{550}$ over the four sub-regions during the period 2000-2009. Significant annual and year-to-year variations are observed especially over IGP and AS directly influenced by the dust activity during May-July. Gautam et al. (2009c) found that dust frequency and 5 intensity during pre-monsoon over northern India depend on rainfall amount, soil moisture, wind speed and monsoon onset. Thus, during the weak monsoon years (2002, $2004,2008)$ the dust activities were higher, thus the aerosol loading was higher over northern AS and IGP; the AOD peak was observed during May-July of 2008 compared to 2007, which was a normal year (Gautam et al., 2009c). The $A O D_{550}$ trends obtained 10 from the linear regression of the monthly-mean values reveal a large increase of about $20.9 \%$ over AS and $22.1 \%$ over BoB, while the increase over NIO seems to be low $(5.2 \%)$. In contrast, Kishcha et al. (2009) using MODIS and MISR data for the period 2000-2008 do not find any significant AOD trend over the oceanic regions if the anthropogenic sources are far away. Very surprisingly and opposite to the general thought, 15 the MODIS data show a negligible AOD trend over IGP on annual basis, attributed to the decreasing trend in late pre-monsoon and monsoon (Fig. 4). The majority of the published works limited the examined period to 2000-2005 and analyzed the AOD trends on annual basis or only in the winter period. Due to lack of AOD trend studies over $\mathrm{BoB}$ and $\mathrm{AS}$ it is not possible to compare the presented results.

The $A O D_{550}$ variation regarding the whole south Asia shows an increase of $\sim 10.17 \%$ (Fig. 5b), which is considered one of the largest AOD increasing trends over the globe (Mishchenko et al., 2009). This increase is believed to be mainly due to increase in anthropogenic aerosols, since Novakov et al. (2003) reported increasing soot and sulfate aerosols as well as greenhouse gases over India since the 1930s, Ramanathan et 25 al. (2007) estimated a mean tropospheric $(<5 \mathrm{~km})$ warming rate of $0.24^{\circ} \mathrm{C} /$ decade over the Himalayan region from 1950s. Figure $5 \mathrm{~b}$ shows the monthly variation of the slope values $\left({ }^{*} 100\right)$ (lower panel) and the respective $A D_{550}(\%)$ variation (upper panel) in the whole south Asia. As we earlier noted these values may be considered rather qualitative and not quantitative, since large deviation in the monthly values may occur

\section{AMTD}

4, 5275-5323, 2011

\section{Contrasting aerosol trends over South Asia}

D. G. Kaskaoutis et al.

\section{Title Page}

Abstract Introduction

Conclusions

Tables References Figures

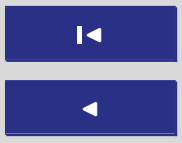
$>$ I

Back

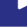
Close Full Screen / Esc

Printer-friendly Version

Interactive Discussion 
depending on the yearly AOD variation. It was found that the trends are statistically significant at $95 \%$ level showing AOD variations up to $20 \%$. Figure $5 \mathrm{~b}$ shows pronounced increase $(>20 \%)$ in $A O D_{550}$ values during winter, while a slight decrease is observed in August and September although not statistically significant.

$5 \quad$ The trends and (\%) variations are much more sensitive to yearly AOD fluctuations when the study area is limited (Fig. 6). This is the case for the period April-July over AS and for May and October over BoB as shown in Fig. 4. On the other hand, both oceanic regions show increasing $A O D_{550}$ trends throughout the year, which are more intense during the winter season, as also observed over NIO. NIO shows large monthly 10 deviations in slope values and \% variations, not allowing any safe conclusion except from post-monsoon and winter. Very contrasting AOD trends are observed over IGP during winter and monsoon. Thus, the following section focuses on AOD variations and trends over IGP aiming at giving some explanations about the observed decreasing trend in monsoon.

15 Since the slope values in the linear regressions and the \% differences in AODs are strongly dependent on the yearly $A O D$ variation, the $A O D_{550}$ over south Asia is obtained for two periods 2000-2005 and 2006-2009 in order to reduce the sensitivity of the trends on the yearly AOD variation. Three seasons were considered for analyzing the AOD differences, (i) winter (January-February), (ii) summer (April-June) and,

(iii) rainy season (July-September). The mean $A O D_{550}$ over each region in the two periods as well as the differences $\left(\triangle A O D_{550}\right)$ are summarized in Table 1 for the three seasons considered. The oceanic regions show increased $A O D_{550}$ during the second half of 2000 s, which can be up to 0.05 over AS (rainy season) and BoB (winter) corresponding to differences of $10-15 \%$. Statistically significant increase in $A O D_{550}$ over

$\mathrm{NIO}$ is observed only in the winter season, while IGP shows large deviation in $\mathrm{AOD}_{550}$ variation, where the increase of $16.5 \%$ during the winter season reverses to $-17.1 \%$ in the rainy season. However, the mean $\triangle A O D$ values during summer and rainy seasons are associated with large standard deviations and must be considered as qualitative.
AMTD

4, 5275-5323, 2011

\section{Contrasting aerosol trends over South Asia}

D. G. Kaskaoutis et al.

\section{Title Page}

Abstract Introduction

Conclusions

Tables

References

Figures

14

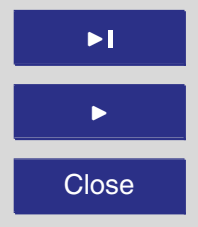

Back

Close

\section{Full Screen / Esc}

Printer-friendly Version

Interactive Discussion 


\section{3 $\mathrm{AOD}_{550}$ variations and trends over IGP}

Initially, we start the analysis of AOD over IGP by showing the longitudinal variation of the latitude-averaged $A O D_{550}$ values on monthly basis (Fig. 7). During winter season a pronounced eastwards increasing AOD is observed highlighting the topographic

5 low eastern IGP as the most aerosol-laden region in the south Asia. Di Girolamo et al. (2004) characterized this region as "the Bihar pollution pool" strongly influencing the aerosol load and properties over the northern BoB. Pre-monsoon seems to be a transition season since in March and April the situation is somewhat similar to that during winter season whereas in the month of May the variation in AOD shows a neutral 10 pattern. The northern part of India has been recognized to be influenced by seasonal (pre-monsoon and monsoon) dust transport from the Thar desert (Singh et al., 2005) strongly affecting the AOD values and variations. This is evident from the large standard deviations during the May-July period where dust activity is at its maximum. The larger AODs in western IGP in late pre-monsoon and early monsoon are attributed to 15 the dust transport vertically distributed up to $4-5 \mathrm{~km}$ influencing the aerosol properties over the Himalayas (Gobbi et al., 2010; Duchi et al., 2011). During the post-monsoon months, the AOD longitudinal variation is rather constant showing larger AOD in the western part in October attributed to extensive crop residue burning in the northwestern IGP (Sharma et al., 2010), while by the end of the post-monsoon the AOD over the eastern IGP again increases.

The analysis of the longitudinal variation of the AOD trends over the IGP during the last decade is shown in Fig. 8. The increasing trend of positive values (increase in AOD) towards eastern IGP in winter season (Kar et al., 2010) suggests that the aerosols over this area, except of the large values, exhibit the largest increasing trend 25 over the whole south Asia, thus enhancing further the "Bihar pollution pool". A similar trend is observed in March, while from April onwards evidence of decreasing AOD is observed, especially for latitudes western from the $80^{\circ} \mathrm{E}$. During May and monsoon months, the AOD trend is always negative, while in view of the large standard deviations
AMTD

4, 5275-5323, 2011

\section{Contrasting aerosol trends over South Asia}

D. G. Kaskaoutis et al.

\section{Title Page}

Abstract Introduction

Conclusions

Tables

References

Figures

14

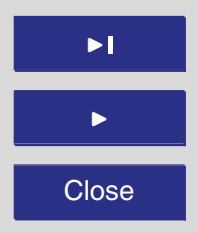

Back

Close

\section{Full Screen / Esc}

Printer-friendly Version

Interactive Discussion 
it is difficult to conclude the trend of the longitudinal variation of the slope values. However, in general, the western part of the region along the longitudes exhibits larger negative values indicating the overall pronounced decreasing AOD trend.

Figure 9 shows the yearly $A O D_{550}$ trends during the winter and summer seasons 5 over four cities located in IGP from northwest to southeast, Amritsar to Kolkata, respectively. These locations closely follow the main pattern in the AOD trend along longitude (Figs. 7 and 8), since the increasing AOD during the winter is more pronounced in the east (Kolkata), while the respective decrease in the summer is much more intense in the west (Amritsar). Decreasing AOD trends over specific locations in 10 IGP during pre-monsoon and monsoon seasons have never been noticed, even using Kanpur AERONET data. The contrasting trends in AOD between these seasons result in vanishing of AOD seasonality by the end of the 2000s, a feature that has never been investigated over IGP. Thus, such analysis of the data observed at the Kanpur AERONET station operating since 2001 will constitute a real challenge, also aiming to 15 justify the MODIS results.

\subsection{Reasons for the declining AOD over IGP}

The larger AODs in the western IGP in April-August and the neighboring Thar desert suggest that the AOD over the area is mainly composed of dust particles during this period. This was also the result of numerous studies performed over northwestern India 20 (e.g. Ganguly et al., 2006b; Kedia and Ramachandran, 2011). Therefore, any AOD variation during pre-monsoon and monsoon months may be related mainly to variation in dust load (Gautam et al., 2009c); the decreasing AOD trend presumes attenuation in dust frequency or intensity, which may be attributed to land use/land cover changes over the Thar desert, variation in soil moisture and/or changes in weather conditions 25 and precipitation.

Land use/land cover changes have been recognized to affect the atmospheric dynamics as well as cloudiness, cloud properties and precipitation (Ray et al., 2006; Douglas et al., 2009). The construction of an irrigation canal carrying water to the
AMTD

4, 5275-5323, 2011

\section{Contrasting aerosol trends over South Asia}

D. G. Kaskaoutis et al.

\section{Title Page}

Abstract Introduction

Conclusions

Tables

References

Figures

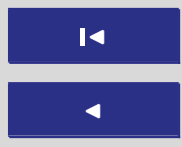

$>$ I

Back

Close

\section{Full Screen / Esc}

Printer-friendly Version

Interactive Discussion

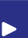

ose

\section{.}


desert (western) and semi-arid (eastern) Rajastan State (northwestern India) resulted in increasing essentially the vegetated areas, the crop production and, subsequently, the economic development (Pandya et al., 2004). The irrigation facility provided by the "Indira Gandhi Canal" has transformed the deserts in to green and greenery and 5 changed the feature of Rajasthan's desert. The analysis of LANDSAT MSS and IRSP6 AWiFS satellite data sets over Rajasthan (paper under preparation) shows that the crop area has increased by $\sim 57 \%$ and $\sim 68 \%$ in eastern and western Rajasthan during the period 1972-1973 to 2006-2007. Douglas et al. (2006) analyzed the changes in water-vapor and energy fluxes between a pre-agricultural and a contemporary agricul10 tural area in India and found $17 \%$ increase in mean annual water-vapor fluxes with an increase in rainfall of $7 \%$ during the period July-December and $55 \%$ during JanuaryMay, indicating a pronounced influence of agriculture on atmospheric moisture and energy fluxes. The expansion of the vegetated areas in Rajasthan has a direct effect on relative humidity and soil moisture over the area and a negative feedback in dust 15 activity. The opposite was found to occur over sub-Sahel savanna, where the drought conditions have expanded the desert areas with a linkage to increasing dust outflow and loading (Engelstaedter et al., 2006).

Figure 10 shows the rainfall amount (a) and the total number of rainy days (b) during the period April-September 1997-2007 over western and eastern Rajastan. The precipitation amount consists of daily gridded rainfall data at $1^{\circ} \times 1^{\circ}$ spatial resolution obtained from the Indian Meteorological Department (IMD) (Rajeevan et al., 2006). The IMD product uses gauge data from 1803 stations to estimate daily accumulated rainfall; the Shepard (1968) interpolation technique was used for gridding data from individual stations over the Indian sub-continent $\left(6.5^{\circ} \mathrm{N}\right.$ to $37.5^{\circ} \mathrm{N}, 66.5^{\circ} \mathrm{E}$ to $\left.101.5^{\circ} \mathrm{E}\right)$.

25 The gridded daily rainfall data over Rajasthan were analyzed to identify the number of rainfall days for each year, which were detected as the days with rainfall amount above " 0 ". Both the rainfall amount and total number of rainy days present an increasing trend over eastern and western Rajasthan, especially during the period 2000-2007 (MODIS observations), maybe as a consequence of the increase in vegetation cover
AMTD

4, 5275-5323, 2011

\section{Contrasting aerosol trends over South Asia}

D. G. Kaskaoutis et al.

\section{Title Page}

Abstract Introduction

Conclusions

Tables

References

Figures

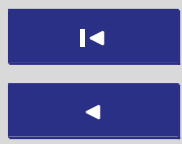

$\Delta$

Back

Close

\section{Full Screen / Esc}

Printer-friendly Version

Interactive Discussion 
and atmospheric moisture. The results show that the increasing trends are more pronounced over western Rajasthan which is located well within the Thar desert. It was also found (not presented) that the expansion of the crop areas was also larger over western Rajasthan limiting the dust source regions.

5 On the other hand, the role of aerosols in the rainfall variability over northern India cannot be ignored, since Gautam et al. (2010) have shown that the radiative heating by absorbing aerosols over IGP may accelerate the pre-monsoon warming and influence the evolution of summer monsoon. Furthermore, modeling studies have suggested the importance of absorbing aerosols in modulating the rainfall re-distribution (Randles and

10 Ramaswamy, 2008). However, the dust activity over IGP can partly be controlled by the changes in land use/land cover over Thar desert and/or changes in precipitation, since the dust source regions that affect northern India are extended further to west, in the Arabian Peninsula and Middle East (Prospero et al., 2002). The dust activity over the region is also controlled by the intensity of the monsoon, synoptic meteorology and

15 wind field. To this respect, the AOD over AS does not follow the decreasing trend found over IGP during May-August. However, IGP is mainly influenced by the Thar desert, while AS is in the downwind region of the Iran-Pakistan dust outflows (Levar winds) and the Arabian peninsula.

\subsection{GOCART simulations}

20 The aerosol and dust simulations from Global Ozone Chemistry Aerosol Radiation and Transport (GOCART) model are obtained over south Asia during 2000-2007 for the months April-September when the dust activity is at its maximum and a decreasing trend in the AOD over northern India was observed. In the GOCART simulations south Asia corresponds to a greater area including the Iranian and Pakistan deserts 25 as well as the Arabian peninsula. Earlier studies (Chin et al., 2002, 2004; Yu et al., 2003) have shown considerable consistency between GOCART simulations and observations (i.e. AERONET, MODIS) over the globe, while recently Chin et al. (2009) analyzed the GOCART simulations and AERONET retrievals over Kanpur showing

\section{AMTD}

4, 5275-5323, 2011

\section{Contrasting aerosol trends over South Asia}

D. G. Kaskaoutis et al.

\section{Title Page}

Abstract Introduction

Conclusions

Tables

References

Figures

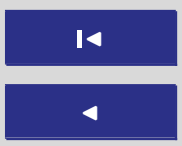

$>$ I

Back

Close

\section{Full Screen / Esc}

Printer-friendly Version

Interactive Discussion
$>$

(1)

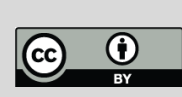


satisfactory regarding the aerosol properties. The GOCART simulations of the total and dust $A O D_{550}$ obtained via Giovanni (http://disc.sci.gsfc.nasa.gov/giovanni) are used in the present study with a spatial resolution of $2^{\circ} \times 2.5^{\circ}$. Detailed information about aerosol types included in the GOCART simulations, emission inventories, errors 5 and uncertainties in the simulations can be found elsewhere (Chin et al., 2009).

Figure 11 shows the GOCART simulations of the monthly variation of the total and dust $A O D_{550}$ (lower panel) and of the dust contribution (\%) to the total $A \mathrm{OD}_{550}$ (upper panel) for the months April to September covering the period 2000-2007. The monthly values correspond to the area $\left(4-35^{\circ} \mathrm{N}, 45-95^{\circ} \mathrm{E}\right)$ and the linear regressions as well 10 as the \% variation of each parameter are shown. The results show that the GOCART simulations are in accordance with MODIS observations for decreasing $A_{O D} D_{550}$ over the region suggesting a pronounced decrease of the dust component $(-25.9 \pm 17.8 \%)$. Furthermore, the dust contribution to the total $\mathrm{AOD}_{550}$ exhibits a considerable decrease over the area $(-26.9 \pm 15.2 \%)$, supporting the declining trend in $\mathrm{AOD}_{550}$ over northern 15 India attributed to the attenuation of dust activity. However, the GOCART simulations are limited to 2007, but except of that, the decreasing trend of dust $A O D_{550}$ can be considered as real.

Furthermore, the spatial distributions of the monthly mean and the \% variation of the dust $A O D_{550}$ are presented in Fig. 12 in order to reveal the regions of enhanced dust load and significant variations. Starting from the dust $A O D_{550}$ the GOCART simulations show increased values over the Arabian Peninsula, Iran and Pakistan deserts, also extended to northwestern India; another region of large dust $A O D_{550}$ is the Taklimakan desert, while the rest of the area presents very low dust $A O D_{550}(<0.15)$. Focusing on the areas with higher dust load, the model simulations show gradually decreasing dust 25 from May to August, while September reveals only limited dust over the Arabian peninsula. This is somewhat opposite to MODIS observations, which show increased AOD till July over the northern part of AS and western IGP, while COGART shows rather similar amounts of dust during April and July over northern AS and significantly lower dust load in the monsoon over the northwestern India. Regarding the dust- $A O D_{550}$
AMTD

4, 5275-5323, 2011

\section{Contrasting aerosol trends over South Asia}

D. G. Kaskaoutis et al.

\section{Title Page}

Abstract Introduction

Conclusions

Tables

References

Figures

14

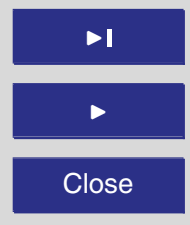

Back

Close

\section{Full Screen / Esc}

Printer-friendly Version

Interactive Discussion 
trends (right panels) a wide range of \% variation is observed in each month. It should be noted that in areas with very low dust load, small trends in the 8-yr period (20002007) can lead to very large \% variations, as the case over NIO in April and over Tibetan Plateau in June. However, these areas are meaningless for examination of 5 the dust variability and we focus our discussions on large dust-affected areas. Thus, the dust load presents an increasing trend over the Arabian peninsula and Middle East during May-July, and partly in September, while over northwestern India a decreasing dust- $\mathrm{AOD}_{550}$ trend $(-10$ to $-50 \%)$ is observed, which is in general agreement with the MODIS observations.

10 As far as the total $A O D_{550}$ is concerned, the mean GOCART simulations for the months April-September show increased values over the Arabian peninsula and northern India, especially in the eastern IGP (Fig. 13a), a feature that is more characteristic during the winter season (see Fig. 1 and Dey and Di Girolamo, 2010). Regarding the $\%$ variations of the total $\mathrm{AOD}_{550}$ and emphasizing over northern India (Fig. 13b), GO-

15 CART simulations reveal a decreasing (increasing) trend in the western (eastern) IGP. Although MODIS observations show a decreasing $\mathrm{AOD}_{550}$ trend over all northern India, one can see a general accordance from the GOCART simulations regarding the negative trends over northwestern India. As expected, the dust contribution to the total $\mathrm{AOD}_{550}$ (Fig. 13c) is much larger over the desert regions gradually decreasing towards east and south. The most important finding from the GOCART simulations is the negative trend of the dust contribution (Fig. 13d), especially over the Indian sub-continent, giving support to our suggestions for attenuation of dust over the region during the period April-September in the last decade.

\section{Conclusions}

25 This study focused on analyzing the AOD variations and trends over south Asia based on Terra-MODIS observations during the last decade (2000-2009) aiming further at investigating the reasons for such decadal changes. The MODIS observations show
AMTD

4, 5275-5323, 2011

\section{Contrasting aerosol trends over South Asia}

D. G. Kaskaoutis et al.

\section{Title Page}

Abstract

Introduction

Conclusions

Tables

References

Figures

14

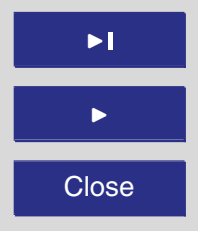

Back

Close

\section{Full Screen / Esc}

Printer-friendly Version

Interactive Discussion 
considerable spatio-temporal variations in AOD as well as in its decadal changes, mainly consisted of a general increasing trend over the whole south Asia, which is more intense during winter season, and a pronounced decreasing AOD trend over IGP during late pre-monsoon and monsoon months (April to September). Since several 5 earlier studies highlighted the increasing aerosol load over south Asia, we focused on the monsoon decreasing trend over IGP aiming to reveal some reasons for that. Since the main aerosol type over northern India in late pre-monsoon and monsoon is dust transported mainly from the Thar desert, we showed its variations in order to explain the decreasing AOD trend over the region. Thus, the decrease in AOD may be closely 10 related to the attenuation of dust activity and the fact that the decreasing AOD trend was more intense in the western rather than eastern IGP justifies such attenuation. The construction of an irrigation canal carrying water in the semi-arid Rajastan state has changed the feature of the Thar desert and extended the crop-land areas. As a consequence, the desert areas in northwestern India have been reduced and the higher air moisture due to vegetated areas led to increase in precipitation, both constitute negative feedbacks for the dust outflows. The GOCART simulations also showed considerable reduction of dust-AOD and its contribution to the total AOD over south Asia during 2000-2007, which are in general agreement with the MODIS observations.

However, the AOD trends as well as their spatial distribution over south Asia, either 20 from MODIS observations or GOCART simulations, may be considered rather qualitatively and not quantitatively due to the short period used for such applications. Thus, the monthly variations of the slope values and (\%) changes in $A O D_{550}$, especially for the four sub-regions, may be strongly modified depending on the yearly AOD variation. Nevertheless, the results showed a pronounced increasing trend in AOD over the whole south Asia, mainly during winter season, and an evidence of decrease in AOD over northern India and IGP during summer, which requires further investigations from ground-based measurements.

\section{AMTD}

4, 5275-5323, 2011

\section{Contrasting aerosol trends over South Asia}

D. G. Kaskaoutis et al.

\section{Title Page}

Abstract Introduction

Conclusions

Tables

References

Figures

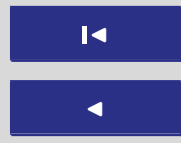

Back

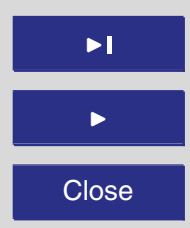

Full Screen / Esc

Printer-friendly Version

Interactive Discussion

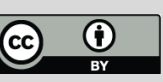


Acknowledgements. We thank the MODIS and GOCART scientific teams for analyzing and providing the data through Giovanni website, as well as the IMD for providing the gridded rainfall data over Rajasthan state.

\section{References}

5 Badarinath, K. V. S., Kharol, S. K., Sharma, A. R., Ramaswamy, V., Kaskaoutis, D. G., and Kambezidis, H. D.: Investigations of an intense aerosol loading during 2007 cyclone SIDR A study using satellite data and ground measurements over Indian region, Atmos. Environ., 43, 3708-3716, 2009.

Badarinath, K. V. S., Sharma, A. R., Kaskaoutis, D. G., Kharol, S. K., and Kambezidis, 10 H. D.: Solar dimming over the tropical urban region of Hyderabad, India: Effect of increased cloudiness and increased anthropogenic aerosols, J. Geophys. Res., 115, D21208, doi:10.1029/2009JD013694, 2010.

Badarinath, K. V. S., Kharol, S. K., Kiran Chand, T. R., and Madhavi Latha, K.: Characterization of aerosol optical depth, aerosol mass concentration, UV irradiance and black carbon aerosols over Indo-Gangetic plains, India, during fog period, Meteorol. Atmos. Phys., 111, 6573, doi:10.1007/s00703-010-0117-5, 2011.

Chin, M., Ginoux, P., Kinne, S., Torres, O., Holben, B., Duncan, B. N., Martin, R. V., Logan, J. A., Higurashi, A., and Nakajima, T.: Aerosol distributions and radiative properties simulated in the GOCART model and comparisons with observations, J. Atmos. Sci., 59, 461-483, 2002.

Chin, M., Diehl, T., Dubovik, O., Eck, T. F., Holben, B. N., Sinyuk, A., and Streets, D. G.: Light absorption by pollution, dust, and biomass burning aerosols: a global model study and evaluation with AERONET measurements, Ann. Geophys., 27, 3439-3464, 2009, http://www.ann-geophys.net/27/3439/2009/.

Chung, C. E., Ramanathan, V., Kim, D., and Podgorny, I. A.: Global anthropogenic aerosol direct forcing derived from satellite and ground-based observations, J. Geophys. Res., 110, D24207, doi:10.1029/2005JD006356, 2005.

Das, S. K., Jayaraman, A., and Misra, A.: Fog induced variations in aerosol optical and physical properties over the Indo-Gangetic Basin and impact to aerosol radiative forcing, Ann. Geo-
AMTD

4, 5275-5323, 2011

\section{Contrasting aerosol trends over South Asia}

D. G. Kaskaoutis et al.

\section{Title Page}

Abstract

Conclusions

References

Tables

Figures

14

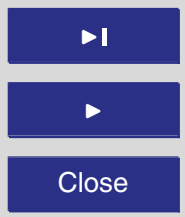

Back

Close

\section{Full Screen / Esc}

Printer-friendly Version

Interactive Discussion 
phys., 26, 1345-1354, 2008,

http://www.ann-geophys.net/26/1345/2008/.

Dey, S. and di Girolamo, L.: A climatology of aerosol optical and microphysical properties over the Indian subcontinent from 9 years (2000-2008) of Multiangle Imaging Spectroradiometer

5 (MISR) data, J. Geophys. Res., 115, D15204, doi:10.1029/2009JD013395, 2010.

Dey, S., Tripathi, S. N., Singh, R. P., and Holben, B. N.: Influence of dust storms on the aerosol optical properties over the Indo-Gangetic plains, J. Geophys. Res., 109, D20211, doi:10.1029/2004JD004924, 2004.

Di Girolamo, L., Bond, T. C., Bramer, D., Diner, D. J., Fettinger, F., Kahn, R. A., Martonchik, J. A., Ramana, M. V., Ramanathan, V., and Rasch, P. J.: Analysis of Multi-angle Imaging SpectroRadiometer (MISR) aerosol optical depths over greater India during winter 20012004, Geophys. Res. Lett., 31, L23115, doi:10.1029/2004GL021273, 2004.

Douglas, E. M., Niyogi, D., Frolking, S., Yeluripati, J. B., Pielke Sr. R. A., Niyogi, N., Vorosmarty, C. J., and Mohanty, U. C.: Changes in moisture and energy fluxes due to agricultural land use and irrigation in the Indian Monsoon Belt, Geophys. Res. Lett., 33, L14403, doi:10.1029/2006GL026550, 2006.

Douglas, E. M., Beltrán-Przekurat, A., Niyogi, D., Pielke, Sr. R. A., and Vorosmarty, C. J.: The impact of agricultural intensification and irrigation on land-atmosphere interactions and Indian monsoon precipitation - A mesoscale modeling perspective, Global Planet. Change, 20 doi:10.1016/j.gloplacha.2008.12.007, 2009.

Duchi, R., Cristofanelli, P., Marinoni, A., Laj, P., Marcq, S., Villani, P., Sellegri, K., Angelini, F., Calzolari, F., Gobbi, G. P., Verza, G. P., Vuillermoz, E., Sapkota, A., and Bonasoni, P.: Continuous observations of synoptic-scale dust transport at the Nepal Climate ObservatoryPyramid (5079 m a.s.I.) in the Himalayas, Atmos. Chem. Phys. Discuss., 11, 4229-4261, doi:10.5194/acpd-11-4229-2011, 2011.

Eck, T. F., Holben, B. N., Sinyuk, A., Pinker, R. T., Goloub, P., Chen, H., Chatenet, B., Li, Z., Singh, R. P., Tripathi, S. N., Reid, J. S., Giles, D. M., Dubovik, O., O'Neill, N. T., Smirnov, A., Wang, P., and Xia, X.: Climatological aspects of the optical properties of fine/coarse mode 859 aerosol mixtures, J. Geophys. Res., 115, D19205, doi:10.1029/2010JD014002, 2010.

30 El-Askary, H., Gautam, R., Singh, R. P., and Kafatos, M.: Dust storms detection over the Indo-Gangetic basin using multi sensor data. Advances in Space Research, 37(4), 728-733, 2006.

Engelstaedter, S., Tegen, I., and Washington, R.: North African dust emissions and transport,

AMTD

4, 5275-5323, 2011

Contrasting aerosol trends over South

Asia

D. G. Kaskaoutis et al.

\section{Title Page}

Abstract

Introduction

Conclusions

Tables

References

Figures

14

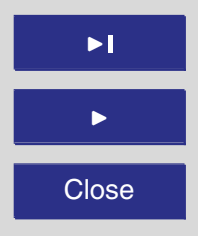

Back

Close

\section{Full Screen / Esc}

Printer-friendly Version

Interactive Discussion 
Earth Sci. Rev., 79, 73-100, 2006.

Ganguly, D., Jayaraman, A., and Gadhavi, H.: In situ ship cruise measurements of mass concentration and size distribution of aerosols over Bay of Bengal and their radiative impacts, J. Geophys. Res., 110, D06205, doi:10.1029/2004JD005325, 2005.

5 Ganguly, D., Jayaraman, A., Rajesh, T. A., and Gadhavi, H.: Wintertime aerosol properties during foggy and nonfoggy days over urban center Delhi and their implications for shortwave radiative forcing, J. Geophys. Res., 111, D15217, doi:10.1029/2005JD007029, 2006a.

Ganguly, D., Jayaraman, A., and Gadhavi, H.: Physical and optical properties of aerosols over an urban location in western India: Seasonal variabilities, J. Geophys. Res., 111, D24206, doi:10.1029/2006JD007392, 2006b.

Gautam, R., Hsu, N. C., Lau, K.-M., and Kafatos, M.: Enhanced pre-monsoon warming over the Himalayan-Gangetic region from 1979 to 2007, Geophys. Res. Lett., 36, L07704, doi:10.1029/2009GL037641, 2009a.

Gautam, R., Hsu, N. C., Lau, K.-M., and Kafatos, M.: Aerosol and rainfall variability over the 15 Indian monsoon region: Distributions, trends and coupling, Ann. Geophys., 29, 3691-3703, 2009b, http://www.ann-geophys.net/29/3691/2009/.

Gautam, R., Liu, Z., Singh, R. P., and Hsu, N. C.: Two contrasting dust-dominant periods over India observed from MODIS and CALIPSO data, Geophys. Res. Lett., 36, L06813, doi:10.1029/2008GL036967, 2009c.

Gautam, R., Hsu, N. C., and Lau, K.-M.: Premonsoon aerosol characterization and radiative effects over the Indo-Gangetic Plains: Implications for regional climate warming, J. Geophys. Res., 115, D17208, doi:10.1029/2010JD013819, 2010.

Giles, D. M., Holben, B. N., Tripathi, S. N., Eck, T., Newcomb, W., Slutsker, I., Dickerson, R., Thompson, A., Mattoo, S., Wang, S., Singh, R., Sinyuk, A., and Schafer, J.: Aerosol Properties over the Indo-Gangetic Plain: A 1 Mesoscale Perspective from the TIGERZ Experiment, J. Geophys. Res., in press, doi:10.1029/2011JD015809, 2011.

Gobbi, G. P., Angelini, F., Bonasoni, P., Verza, G. P., Marinoni, A., and Barnaba, F.: Sunphotometry of the 2006-2007 aerosol optical/radiative properties at the Himalayan Nepal doi:10.5194/acp-10-11209-2010, 2010.

Gogoi, M., Pathak, B., Moorthy, K. K., Bhuyan, P. K., Suresh Babu, S., Bhuyan, K., and Kalita, G.: Mutli-year investigations of near surface and columnar aerosols over Dibrugarh, north- 
eastern location of India: Heterogeneity in source impacts, Atmos. Environ., 45, 1714-1724, 2011.

Goloub, P., Deuze, J. L., Herman, M., Marchand, A., Tanre, D., Chiapello, I., Roger, B., and Singh, R. P.: Aerosols remote sensing over land using the spaceborne polarimeter POLDER, 5 in: IRS 2000: Current problems in Atmospheric Radiation, edited by: Smith, W. L., Timofeyev, Yu, M., A. Deepak Publishing, Hampton, Virginia, 113-116, 2001.

Habib, G., Venkataraman, C., Chiapello, I., Ramachandran, S., Boucher, O., and Reddy, M. S.: Seasonal and interannual variability in absorbing aerosols over India derived from TOMS: Relationship to regional meteorology and emissions, Atmos. Environ., 40(11), 1909-1921, 2006.

IPCC: Summary for Policymakers, in: Climate Change 2007. The Physical Science Basis. Contribution of Working Group I to the Fourth Assessment Report of the Intergovernmental Panel on Climate Change, edited by: Solomon, S., Qin, D., Manning, M., Chen, Z., Marquis, M., Averyt, K. B., Tignor, M., and Miller, H. L., (Cambridge, United Kingdom and New York, NY, USA, Cambridge University Press), 2007.

Jethva, H., Satheesh, S. K., and Srinivasan, J.: Seasonal variability of aerosols over the IndoGangetic basin, J. Geophys. Res., 110, D21204, doi:10.1029/2005JD005938, 2005.

Jethva, H., Satheesh, S. K., and Srinivasan, J.: Evaluation of Moderate-Resolution Imaging Spectroradiometer (MODIS) Collection 004 (C004) aerosol retrievals at Kanpur, Indo-

20 Gangetic Basin, J. Geophys. Res., 112, D14216, doi:10.1029/2006JD007929, 2007.

Kahn, R., Petzold, A., Wendisch, M., Bierwirth, E., Dinter, T., Esselborn, M., Fiebig, M., Heese, B., Knippertz, P., Müller, D., Schladitz, A., and von Hoyningen-Huene, W.: Desert dust aerosol air mass mapping in the western Sahara, using particle properties derived from space-based multi-angle imaging, Tellus B, 61, 239-251, 2009.

Kalapureddy, M. C. R., Kaskaoutis, D. G., Ernest Raj, P., Devara, P. C. S., Kambezidis, H. D., Kosmopoulos, P. G., and Nastos, P. T.: Identification of aerosol type over the Arabian Sea in the pre-monsoon season during the ICARB campaign, J. Geophys. Res., 114, D17203, doi:10.1029/2009JD011826, 2009.

Kar, J., Deeter, M. N., Fishman, J., Liu, Z., Omar, A., Creilson, J. K., Trepte, C. R., Vaughan, M. A., and Winker, D. M.: Wintertime pollution over the Eastern Indo-Gangetic Plains as observed from MOPITT, CALIPSO and tropospheric ozone residual data, Atmos. Chem. Phys., 10, 12273-12283, doi:10.5194/acp-10-12273-2010, 2010.

Kaskaoutis, D. G., Badarinath, K. V. S., Kharol, S. K., Sharma, A. R., and Kambezidis, H. D.:

\section{AMTD}

4, 5275-5323, 2011

\section{Contrasting aerosol trends over South Asia}

D. G. Kaskaoutis et al.

\section{Title Page}

Abstract

Introduction

Conclusions

References

Tables

Figures
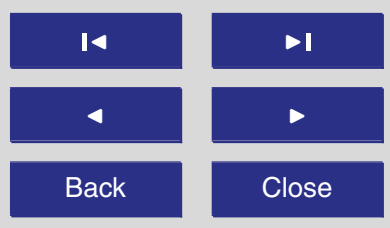

Back

Close

\section{Full Screen / Esc}

Printer-friendly Version

Interactive Discussion 
Variations in the aerosol optical properties and types over the tropical urban site of Hyderabad, India, J. Geophys. Res., 114, D22204, doi:10.1029/2009JD012423, 2009.

Kaskaoutis, D. G., Kalapureddy, M. C. R., Krishna Moorthy, K., Devara, P. C. S., Nastos, P. T., Kosmopoulos, P. G., and Kambezidis, H. D.: Heterogeneity in pre-monsoon aerosol types 5 over the Arabian Sea deduced from ship-borne measurements of spectral AODs, Atmos. Chem. Phys., 10, 4893-4908, doi:10.5194/acp-10-4893-2010, 2010.

Kaskaoutis, D. G., Kumar Kharol, S., Sinha, P. R., Singh, R. P., Kambezidis, H. D., Rani Sharma, A., and Badarinath, K. V. S.: Extremely large anthropogenic-aerosol contribution to total aerosol load over the Bay of Bengal during winter season, Atmos. Chem. Phys., 11, 70977117, doi:10.5194/acp-11-7097-2011, 2011.

Kedia, S. and Ramachandran, S.: Seasonal variations in aerosol characteristics over an urban location and a remote site in western India, Atmos. Environ., 45, 2120-2128, 2011.

Kharol, S. K., Badarinath, K. V. S., Sharma, A. R., Kaskaoutis, D. G., and Kambezidis, H. D.: Multiyear analysis of Terra/Aqua MODIS aerosol optical depth and ground observations over

15 tropical urban region of Hyderabad, India, Atmos. Environ., 45, 1532-1542, 2011.

Kishcha, P., Starobinets, B., Kalashnikova, O., Long, C., and Alpert, P.: Variations in meridional aerosol distribution and solar dimming, J. Geophys. Res., 114, D00D14, doi:10.1029/2008JD010975, 2009.

Kishcha, P., Starobinets, B., Kalashnikova, O., and Pinhas, A.: Aerosol optical thickness 20 trends and population growth in the Indian subcontinent. Int. J. Remote. Sens., in press, doi:10.1080/01431161.2010.550333, 2011.

Krishnamurthi, T. N., Jha, B., Prospero, J., Jayaraman, A., and Ramanathan, V.: Aerosol and pollutant transport and their impact on radiative forcing over the tropical Indian Ocean during the January-February 1996 pre-INDOEX cruise, Tellus B, 521-542, 1998.

Kumar, A., Sarin, M. M., and Srinivas, B.: Aerosol iron solubility over Bay of Bengal: Role of anthropogenic sources and chemical processing, Mar. Chem., 121, 167-175, 2010.

Lau, K. M., Kim, M. K., and Kim, K. M.: Asian summer monsoon anomalies induced by aerosol direct forcing: the role of the Tibetan Plateau, Clim. Dynam., 26, 855-864, 2006.

Lawrence, M. G. and Lelieveld, J.: Atmospheric pollutant outflow from southern Asia: a review,

$30 \quad$ Atmos. Chem. Phys., 10, 11017-11096, doi:10.5194/acp-10-11017-2010, 2010.

Levy, R. C., Remer, L. A., Mattoo, S., Vermote, E., and Kaufman, Y. J.: Second-generation operational algorithm: Retrieval of aerosol properties over land from inversion of Moderate Resolution Imaging Spectroradiometer spectral reflectance, J. Geophys. Res., 112, D13211,

\section{AMTD}

4, 5275-5323, 2011

\section{Contrasting aerosol trends over South Asia}

D. G. Kaskaoutis et al.

\section{Title Page}

Abstract

Introduction

Conclusions

Tables

References

Figures

14

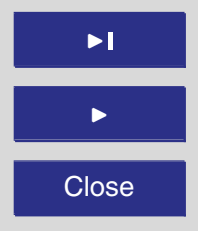

Back

\section{Full Screen / Esc}

Printer-friendly Version

Interactive Discussion

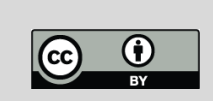


doi:10.1029/2006JD007811, 2007.

Massie, S. T., Torres, O., and Smith, S. J.: Total Ozone Mapping Spectrometer (TOMS) observations of increases in Asian aerosol in winter from 1979 to 2000, J. Geophys. Res., 109(D18), D18211, doi:10.1029/2004JD004620, 2004.

5 Menon, S., Hansen, J., Nazarenko, L., and Luo, Y.: Climate effects of black carbon aerosols in China and India, Science, 297, 2250-2253, 2002.

Mishchenko, M. I., Geogdzhayev, I. V., Liu, L., Lacis, A., Cairns, B., and Travis, L. D.: Toward unified satellite climatology of aerosol properties: What do fully compatible MODIS and MISR aerosol pixels tell us?, J. Quant. Spectrosc. Ra., 110, 402-408, 2009.

10 Moorthy, K. K., Babu, S. S., and Satheesh, S. K.: Aerosol spectral optical depths over Bay of Bengal: Role of transport, Geophys. Res. Lett., 30(5), 1249, doi:10.1029/2002GL016520, 2003.

Moorthy, K. K., Babu, S. S., and Satheesh, S. K.: Aerosol characteristics and radiative impacts over the Arabian Sea during the intermonsoon season: Results from ARMEX field campaign,

Moorthy, K. K., Satheesh, S. K., Babu, S. S., and Dutt, C. B. S.: Integrated Campaign for Aerosols, gases and Radiation Budget (ICARB): An overview, J. Earth Syst. Sci., 117, 243262, 2008.

Moorthy, K. K., Beegum, S. N., Babu, S. S., Smirnov, A., John, S. R., Kumar, K. R., Narasimhulu, K., Dutt, C. B. S., and Nair, V. S.: Optical and physical characteristics of Bay of Bengal aerosols during W_ICARB: Spatial and vertical heterogeneities in the MABL and in the vertical column, J. Geophys. Res., 115, D24213, doi:10.1029/2010JD014094, 2010.

Nair, V. S., Moorthy, K. K., Babu, S. S., and Satheesh, S. K.: Optical and physical properties of atmospheric aerosols over the Bay of Bengal during ICARB, J. Atmos. Sci., 66, 2640-2658, 2009.

Nair, V. S., Satheesh, S. K., Moorthy, K. K., Babu, S. S., Nair, P. R., and George, S. K.: Surprising observation of large anthropogenic aerosol fraction over the "nearpristine" southern Bay of Bengal: Climate implications, J. Geophys. Res., 115, D21201, doi:10.1029/2010JD013954, 2010.

so Novakov, T., Ramanathan, V., Hansen, J. E., Kirchstetter, T. W., Sato, M., Sinton, J. E., and Sathaye, J. A.: Large historical changes of fossil-fuel black carbon aerosols, Geophys. Res. Lett., 30, 1324, doi:10.1029/2002GL016345, 2003.

Ohmura, A.: Observed decadal variations in surface solar radiation and their causes, J. Geo-
AMTD

4, 5275-5323, 2011

Contrasting aerosol trends over South

Asia

D. G. Kaskaoutis et al.

\section{Title Page}

Abstract

Introduction

Conclusions

Tables

References

Figures

14

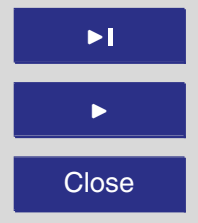

Back

Close

\section{Full Screen / Esc}

Printer-friendly Version

Interactive Discussion 
phys. Res., 114, D00D05, doi:10.1029/2008JD011290, 2009.

Pandya, M. R., Singh, R. P., and Dadhwal, V. K.: A signal of increased vegetation activity of India from 1981 to 2001 observed using satellite-derived fraction of absorbed photosynthetically active radiation, Curr. Sci., 87(8), 1122-1126, 2004.

5 Pathak, B., Kalita, G., Bhuyan, P. K., and Moorthy, K. K.: Aerosol temporal characteristics and its impact on shortwave radiative forcing at a location in the northeast of India, J. Geophys. Res., 115, D19204, doi:10.1029/2009JD013462, 2010.

Prasad, A. K. and Singh, R. P.: Comparison of MISR-MODIS aerosol optical depth over the Indo-Gangetic basin during the winter and summer seasons (2000-2005), Remote. Sens.

$10 \quad$ Environ., 107, 109-119, 2007.

Prasad, A. K., Singh, R. P., and Singh, A.: A variability of aerosol optical depth over Indian sub-continent using MODIS data, J. Indian Soc. Remote Sens. 32, 313-316, 2004.

Prasad, A. K., Singh, R. P., and Kafatos, M.: Influence of coal based thermal power plants on aerosol optical properties in the Indo-Gangetic basin, Geophys. Res. Lett., 33, L05805, doi:10.1029/2005GL023801, 2006.

Prasad, A. K., Sarkar, S., Singh, R. P., and Kafatos, M.: Inter-annual variability of vegetation cover and rainfall over India, Adv. Space Res., 39, 79-87, 2007.

Prospero, J. M., Ginoux, P., Torres, O., Nicholson, S. E., and Gill, T.: Environmental characterization of global sources of atmospheric soil dust identified with Nimbus 7 Total Ozone Mapping Spectrometer (TOMS) absorbing aerosol product, Rev. Geophys., 40, 1002, doi:10.1029/2000RG000095, 2002.

Raghavendra Kumar, K., Narasimhulu, K., Balakrishnaiah, G., Reddy, B. S. K., Rama Gopal, K., Reddy, R. R., Reddy, L. S. S., Moorthy, K. K., Babu, S. S., and Dutt, C. B. S.: Spatial heterogeneities in aerosol properties over Bay of Bengal inferred from ship-borne and MODIS observations during ICARB-W cruise campaign: Implications to radiative forcing, Atmos. Environ., 45, 404-412, 2011.

Rajeevan, M., Bhate, J., Kale, J. D., and Lal, B.: High resolution daily gridded rainfall data for the Indian region: Analysis of break and active monsoon spells, Curr. Sci., 91(3), 296-306, 2006.

30 Ramachandran, S.: Spectral aerosol optical characteristics during the northeast monsoon over the Arabian Sea and the tropical Indian Ocean: 2. Angstrom and anthropogenic influence, J. Geophys. Res., 109, D19208, doi:10.1029/2003JD004483, 2004.

Ramachandran, S.: Aerosol optical depth and fine mode fraction variations deduced from Mod-
AMTD

4, 5275-5323, 2011

Contrasting aerosol trends over South Asia

D. G. Kaskaoutis et al.

\section{Title Page}

Abstract

Introduction

Conclusions

Tables

References

Figures

14

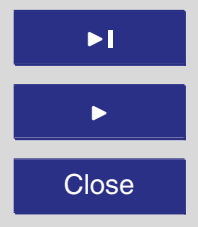

Back

Close

\section{Full Screen / Esc}

Printer-friendly Version

Interactive Discussion 
erate Resolution Imaging Spectroradiometer (MODIS) over four urban areas in India, J. Geophys. Res., 112, D16207, doi:10.1029/2007JD008500, 2007.

Ramachandran, S. and Cherian, R.: Regional and seasonal variations in aerosol optical characteristics and their frequency distributions over India during 2001-2005, J. Geophys. Res., 113, D08207, doi:10.1029/2007JD008560, 2008.

Ramachandran, S. and Jayaraman, A.: Spectral aerosol optical depths over Bay of Bengal and Chennai: II - Sources, anthropogenic influence and model estimates, Atmos. Env., 37, 1951-1962, 2003.

Ramachandran, S. and Kedia, S.: Black carbon aerosols over an urban region: Radiative forcing and climate impact, J. Geophys. Res., 115, D10202, doi:10.1029/2009JD013560, 2010.

Ramachandran, S., Rengarajan, R., Jayaraman, A., Sarin, M. M., and Das, S. K.: Aerosol radiative forcing during clear, hazy, and foggy conditions over a continental polluted location in north India, J. Geophys. Res., 111, D20214, doi:10.1029/2006JD007142, 2006.

15 Ramanathan, V., Crutzen, P. J., Lelieveld, J., Mitra, A. P., Althausen, D., Anderson, J., Andreae, M. O., Cantrell, W., Cass, G. R., Chung, C. E., Clarke, A. D., Coakley, J. A., Collins, W. D., Conant, W. C., Dulac, F., Heintzenberg, J., Heymsfield, A. J., Holben, B., Howell, S., Hudson, J., Jayaraman, A., Kiehl, J. T., Krishnamurti, T. N., Lubin, D., McFarquhar, G., Novakov, T., Ogren, J. A., Podgorny, I. A., Prather, K., Priestley, K., Prospero, J. M., Quinn, P. K., Rajeev, K., Rasch, P., Rupert, S., Sadourny, R., Satheesh, S. K., Shaw, G. E., Sheridan, P., and Valero, F. P. J.: Indian Ocean Experiment: An Integrated analysis of the climate forcing and effects of the great Indo-Asian haze, J. Geophys. Res., 106, 28371-28398, 2001.

Ramanathan, V., Chung, C., Kim, D., Bettge, T., Buja, L., Kiehl, J. T., Washington, W. M., Fu, Q., Sikka, D. R., and Wild, M.: Atmospheric brown clouds: Impacts on South Asian climate and hydrological cycle, Proc. Natl. Acad. Sci., 102(15), 5326-5333, doi:10.1073/pnas.0500656102, 2005.

Ramanathan, V., Ramana, M. V., Roberts, G., Kim, D., Corrigan, C. E., Chung, C. E., and Winker, D.: Warming trends in Asia amplified by brown cloud solar absorption, Nature, 448, 575-578, 2007.

30 Randles, C. A. and Ramaswamy, V.: Absorbing aerosols over Asia: A geophysical Fluid Dynamics Laboratory general circulation model sensitivity study of model response to aerosol optical depth and aerosol absorption, J. Geophys. Res., 113, D21203, doi:10.1029/2008JD010140, 2008.

\section{AMTD}

4, 5275-5323, 2011

\section{Contrasting aerosol trends over South Asia}

D. G. Kaskaoutis et al.

\section{Title Page}

Abstract Introduction

Conclusions

Tables

References

Figures

14

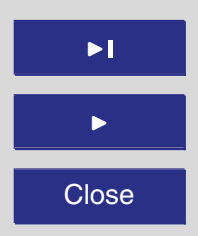

Back

Close

\section{Full Screen / Esc}

Printer-friendly Version

Interactive Discussion 
Ray, D. K., Nair, U. S., Lawton, R. O., Welch, R. M., and Pielke, R. A. Sr.: Impact of land use on Costa Rican tropical montane cloud forests: Sensitivity of orographic cloud formation to deforestation in the plains, J. Geophys. Res., 111, D02108, doi:10.1029/2005JD006096, 2006.

5 Reddy, M. S. and Venkataraman, C.: Inventory of aerosol and sulphur dioxide emission from India: II-Biomass combustion, Atmos. Environ., 36, 699-712, 2002.

Rosenfeld, D., Lohmann, U., Raga, G. B., O' Dowd, C. D., Kulmala, M., Fuzzi, S., Reissell, A., and Andreae, M. O.: Flood or Drought: How do aerosols affect precipitation?, Science, 321, 1309, doi:10.1126/science.1160606, 2008.

10 Sarkar, S., Chokngamwong, R., Cervone, G., Singh, R. P., and Kafatos, M.: Variability of aerosol optical depth and aerosol forcing over India, Adv. Space Res., 37, 2153-2159, 2006.

Sarkar, S., Chiu, L., Kafatos, M., and Singh, R.: Sensitivity of rainfall on land cover change over South East Asia: Some observational results, Adv. Space Res., 39, 73-78, 2007.

Satheesh, S. K. and Moorthy, K.: Radiative effects of natural aerosols: A review, Atmos. Envi15 ron., 35, 2089-2110, 2005.

Satheesh, S. K., Ramanathan, V., Holben, B. N., Moorthy, K. K., Loeb, N. G., Maring, H., Prospero, J. M., and Savoie, D.: Chemical, microphysical, and radiative effects of Indian Ocean aerosols, J. Geophys. Res., 107(D23), 4725, doi:10.1029/2002JD002463, 2002.

Satheesh, S. K., Moorthy, K. K., Kaufman, Y. J., and Takemura, T.: Aerosol optical depth, 20 physical properties and radiative forcing over the Arabian Sea, Meteorol. Atmos. Phys., 91, 45-62, 2006.

Satheesh, S. K., Vinoj, V., and Moorthy, K. K.: Assessment of Aerosol Radiative Impact over Oceanic Regions Adjacent to Indian Subcontinent Using Multisatellite Analysis, Advances in Meteorology, ID 139186, doi:10.1155/2010/139186, 2010.

Sharma, A. R., Kharol, S. K., Badarinath, K. V. S., and Singh, D.: Impact of agriculture crop residue burning on atmospheric aerosol loading - a study over Punjab State, India, Ann. Geophysicae, 28, 367-379, 2010.

Shepard, D.: A two-dimensional interpolation function for irregularly spaced data. In proceedings of the 1968 23rd ACM National Conference, 517-523, 1968.

30 Sinha, P. R., Manchanda, R. K., Subbaro, J. V., Dumka, U. C., Sreenivasan, S., Babu, S. S., and Moorthy, K. K.: Spatial distribution and vertical structure of the MABL aerosols over the Bay of Bengal during winter: Results from W-ICARB experiment, J. Atmos. Solar Terr. Physics, 73, 430-438, 2010.

\section{AMTD}

4, 5275-5323, 2011

Contrasting aerosol trends over South Asia

D. G. Kaskaoutis et al.

\section{Title Page}

Abstract

Introduction

Conclusions

Tables

References

Figures

14

DI

4

Back

\section{Full Screen / Esc}

Printer-friendly Version

Interactive Discussion 
Singh, R. P.: Interactive comment on "Inferring absorbing organic carbon content from AERONET data" by A. Arola et al., Interactive Comment on Atmos. Chem. Phys. Discuss., 10, 18365-18388, 2010,

http://www.atmos-chem-phys-discuss.net/10/18365/2010/.

5 Singh, R. P., Dey, S., Tripathi, S. N., Tare, V., and Holben, B.: Variability of aerosol parameters over Kanpur, northern India, J. Geophys. Res., 109, D23206, doi:10.1029/2004JD004966, 2004.

Singh, S., Nath, S., Kohli, R., and Singh, R.: Aerosols over Delhi during pre-monsoon months: Characteristics and effects on surface radiation forcing, Geophys. Res. Lett., 32, L13808, doi:10.1029/2005GL023062, 2005.

Vadrevu, K. P., Ellicott, E., Badarinath, K. V. S., and Vermote, E.: MODIS derived fire characteristics and aerosol optical depth variations during the agricultural residue burning season, north India, Environ. Pollut., 159(6), 1560-1569, 2011.

Vinoj, V., Babu, S. S., Satheesh, S. K., Moorthy, K. K., and Kaufman, Y. J.: Radiative forcing 15 by aerosols over the Bay of Bengal region derived from shipborne, island-based, and satellite (Moderate-Resolution Imaging Spectroradiometer) observations, J. Geophys. Res., 109, D05203, doi:10.1029/2003JD004329, 2004.

Vinoj, V., Anjan, A., Sudhakar, M., Satheesh, S. K., Srinivasan, J., and Moorthy, K. K.: Latitudinal variation of aerosol optical depths from northern Arabian Sea to Antarctica, Geophys.

$20 \quad$ Res. Lett., 34, L10807, doi:10.2029/2007GL029419, 2007.

Vinoj, V., Satheesh, S. K., and Moorthy, K. K.: Optical, radiative and source characteristics of aerosols at Minicoy, a remote island in the southern Arabian Sea, J. Geophys. Res., 115, D01201, doi:10.1029/2009JD011810, 2010.

Yu, H., Dickinson, R. E., Chin, M., Kaufman, Y. J., Holben, B. N., Geogdhayev, I. V., and 25 Mishchenko, M. I.: Annual cycle of global distributions of aerosol optical depth from integration of MODIS retrievals and GOCART model simulations, J. Geophys. Res., 108(D3), 4128, doi:10.1029/2002JD002717, 2003.

\section{AMTD}

4, 5275-5323, 2011

\section{Contrasting aerosol trends over South Asia}

D. G. Kaskaoutis et al.

\section{Title Page}

Abstract

Introduction

Conclusions

References

Tables

Figures

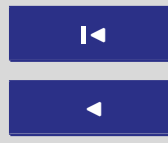

Back

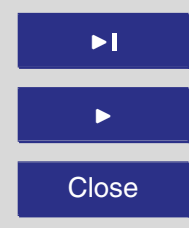

Full Screen / Esc

Printer-friendly Version

Interactive Discussion 


\section{AMTD}

4, 5275-5323, 2011

Table 1. Mean area-averaged $A O D_{550}$ values for the periods 2000-2005 and 2006-2009 in four regions over south Asia and $\triangle \mathrm{AOD}_{550}$ in absolute and percentage values between the two periods for winter (December-February), summer (April-June) and rainy (July-September) seasons.

\begin{tabular}{llrrrr}
\hline \multirow{2}{*}{ Region } & Season & $\begin{array}{r}\text { Mean AOD } \\
(2000-2005)\end{array}$ & $\begin{array}{r}\text { Mean AOD } \\
(2006-2009)\end{array}$ & $\Delta$ AOD & $\Delta$ AOD (\%) \\
\hline \multirow{3}{*}{ AS } & winter & $0.209 \pm 0.038$ & $0.249 \pm 0.043$ & $0.040 \pm 0.015$ & $15.74 \pm 5.37$ \\
& summer & $0.376 \pm 0.068$ & $0.425 \pm 0.088$ & $0.048 \pm 0.040$ & $10.53 \pm 7.84$ \\
& rainy & $0.502 \pm 0.151$ & $0.553 \pm 0.151$ & $0.051 \pm 0.050$ & $9.29 \pm 8.16$ \\
\multirow{3}{*}{ BoB } & winter & $0.242 \pm 0.062$ & $0.291 \pm 0.088$ & $0.049 \pm 0.028$ & $15.81 \pm 5.28$ \\
& summer & $0.348 \pm 0.097$ & $0.383 \pm 0.110$ & $0.035 \pm 0.043$ & $7.92 \pm 11.09$ \\
& rainy & $0.300 \pm 0.041$ & $0.335 \pm 0.056$ & $0.035 \pm 0.039$ & $9.56 \pm 9.83$ \\
NIO & winter & $0.164 \pm 0.036$ & $0.186 \pm 0.039$ & $0.023 \pm 0.014$ & $12.01 \pm 7.09$ \\
& summer & $0.184 \pm 0.052$ & $0.181 \pm 0.058$ & $-0.003 \pm 0.018$ & $-2.76 \pm 9.31$ \\
& rainy & $0.188 \pm 0.044$ & $0.194 \pm 0.046$ & $0.006 \pm 0.012$ & $2.85 \pm 6.31$ \\
IGP & winter & $0.407 \pm 0.142$ & $0.489 \pm 0.173$ & $0.082 \pm 0.046$ & $16.49 \pm 6.74$ \\
& summer & $0.619 \pm 0.159$ & $0.567 \pm 0.141$ & $-0.042 \pm 0.041$ & $-7.19 \pm 6.49$ \\
& rainy & $0.567 \pm 0.153$ & $0.499 \pm 0.145$ & $-0.068 \pm 0.085$ & $-17.14 \pm 22.67$ \\
\hline
\end{tabular}

\section{Contrasting aerosol trends over South Asia}

D. G. Kaskaoutis et al.

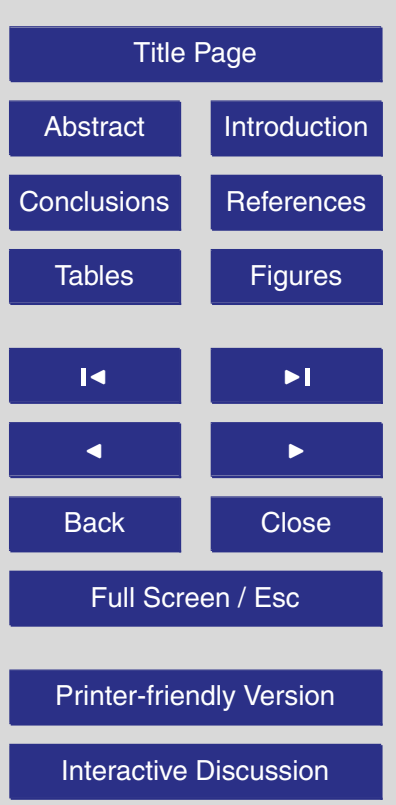



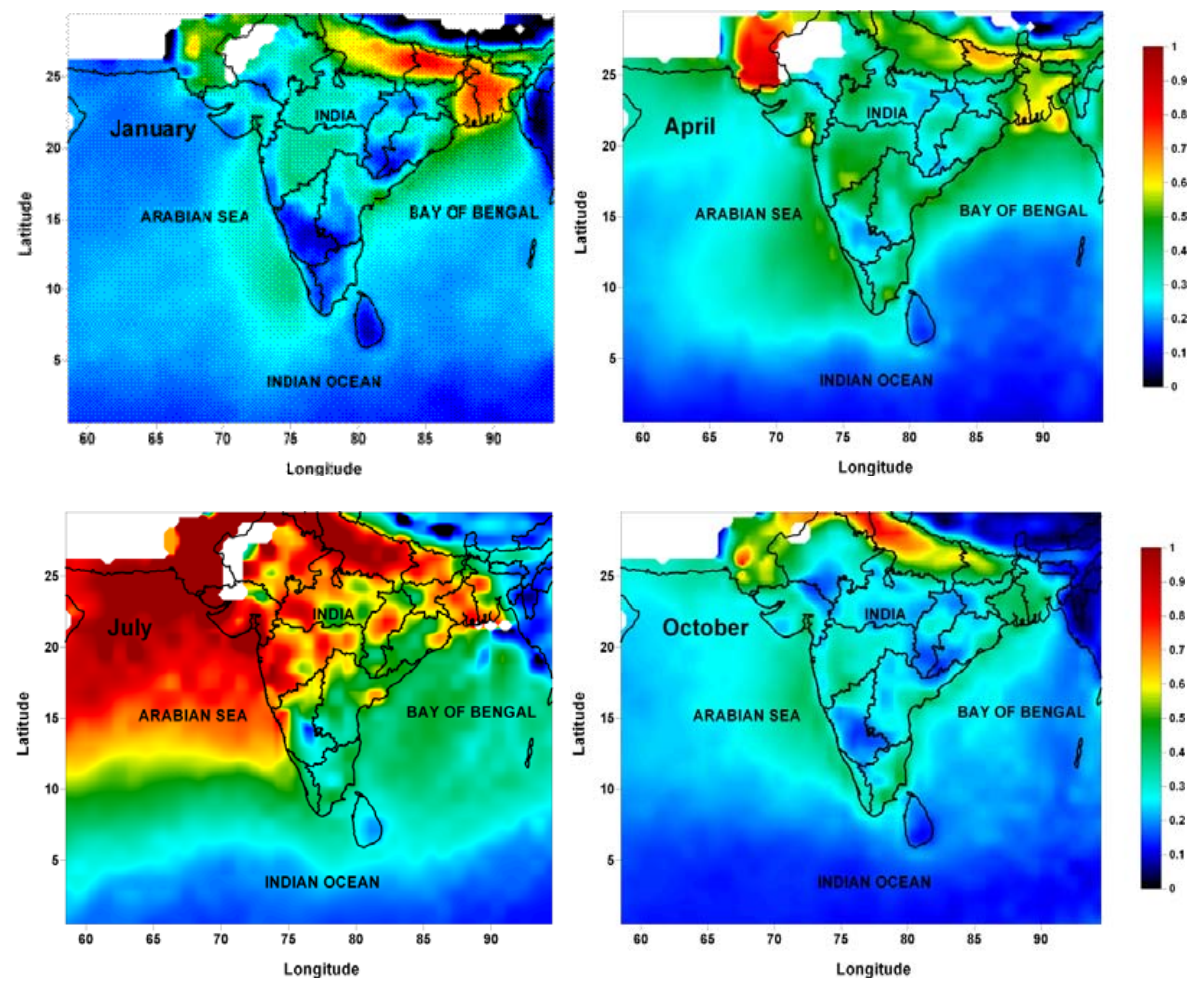

Fig. 1. Monthly-mean spatial distribution of the Terra-MODIS $A^{O O D_{550}}$ over south Asia during the period 2000-2009 for characteristic months in each season (January for winter, April for pre-monsoon, July for monsoon, October for post-monsoon).

AMTD

4, 5275-5323, 2011

Contrasting aerosol trends over South

\section{Asia}

D. G. Kaskaoutis et al.

\section{Title Page}

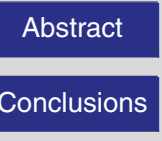

Introduction

\section{Tables}

References

Tables

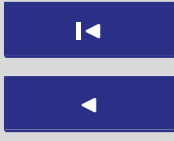

Figures

Back

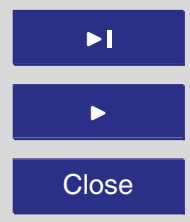

Full Screen / Esc

Printer-friendly Version

Interactive Discussion 

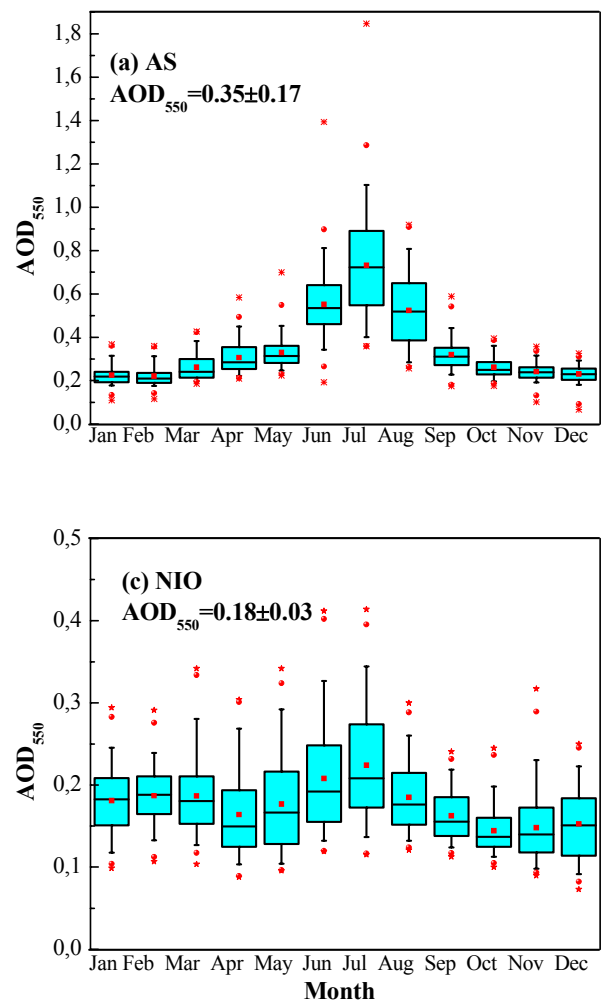
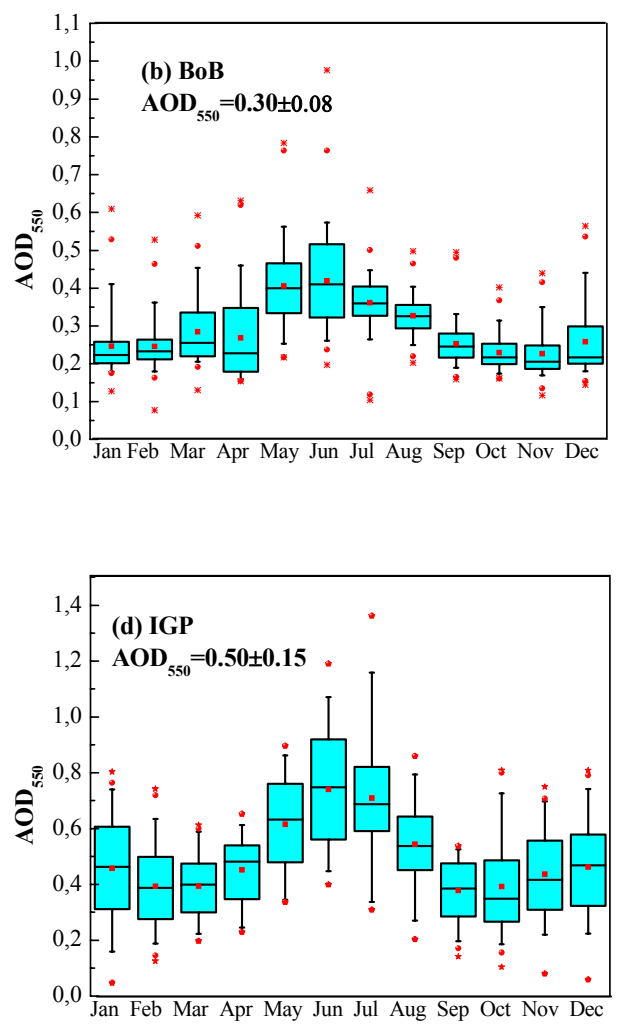

Fig. 2. Monthly variation of the area-averaged Terra-MODIS $A D_{550}$ values over 4 sub-regions in south Asia (a) AS, (b) BoB, (c) NIO and (d) IGP. Box: 25-75\%, $\lambda$ : 1\%, $99 \%$ percentile, $\leftrightarrow$ : min, max value. $v$ : mean value.
AMTD

4, 5275-5323, 2011

\section{Contrasting aerosol trends over South \\ Asia}

D. G. Kaskaoutis et al.

\section{Title Page}

Abstract

Introduction

Conclusions

References

Tables

Figures

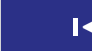

1

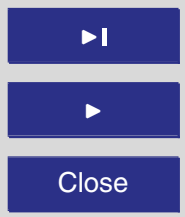

Back

Close

\section{Full Screen / Esc}

Printer-friendly Version

Interactive Discussion 


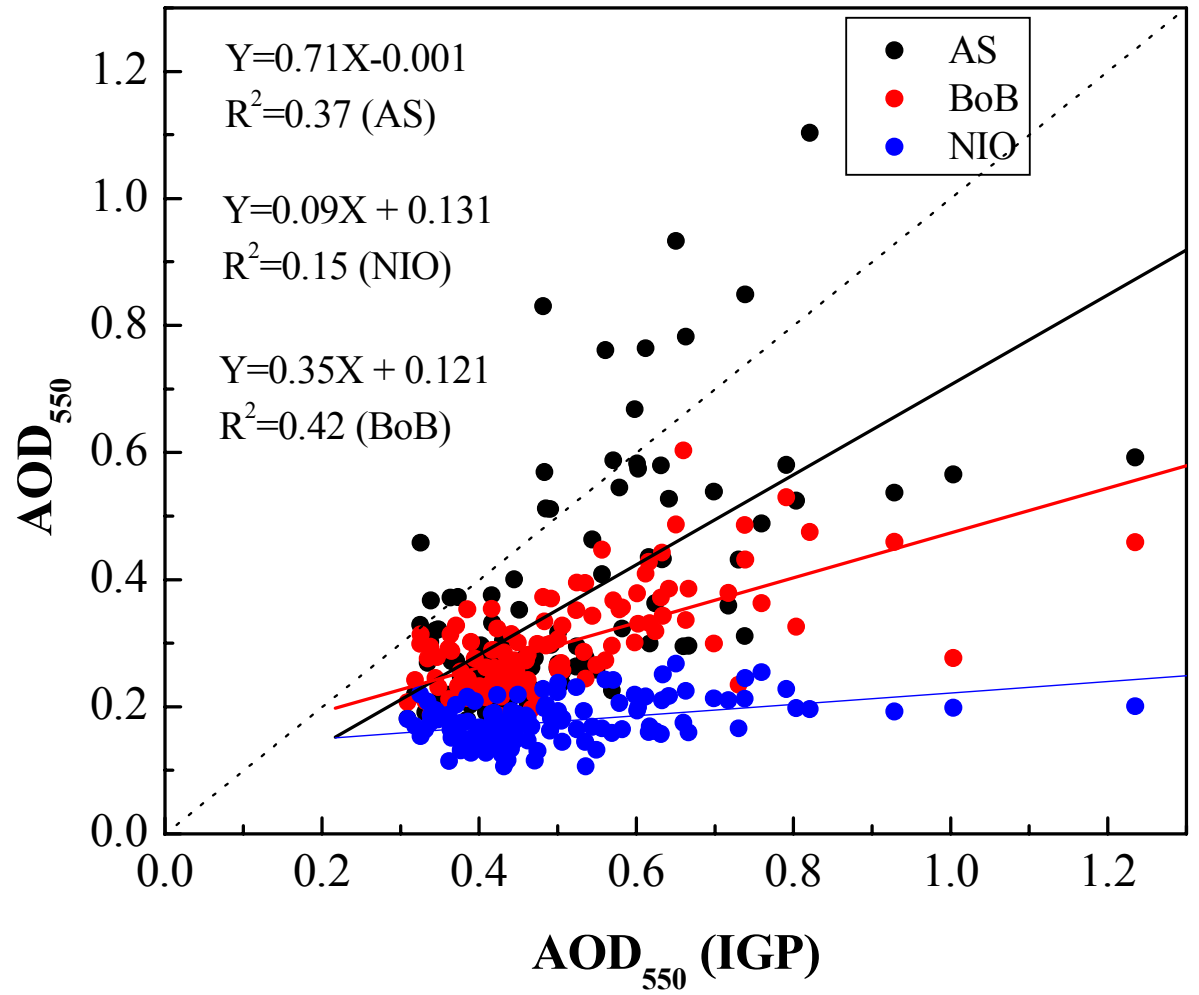

Fig. 3. Correlation between the area-averaged monthly mean MODIS-AOD 550 values over IGP with those obtained over AS, BoB and NIO.
AMTD

4, 5275-5323, 2011

Contrasting aerosol trends over South

Asia

D. G. Kaskaoutis et al.

\section{Title Page}

\begin{tabular}{c|c}
\hline Abstract & Introduction \\
\hline Conclusions & References \\
\hline Tables & Figures \\
\hline I4 & - I \\
\hline 4 & - \\
\hline Back & Close \\
\hline Full Screen / Esc
\end{tabular}

Printer-friendly Version

Interactive Discussion

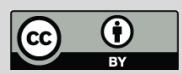



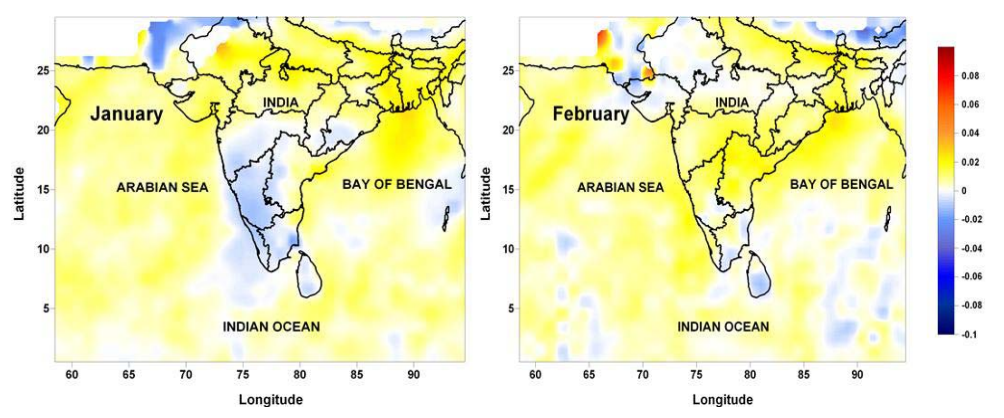

AMTD

4, 5275-5323, 2011

\section{Contrasting aerosol trends over South \\ Asia}

D. G. Kaskaoutis et al.
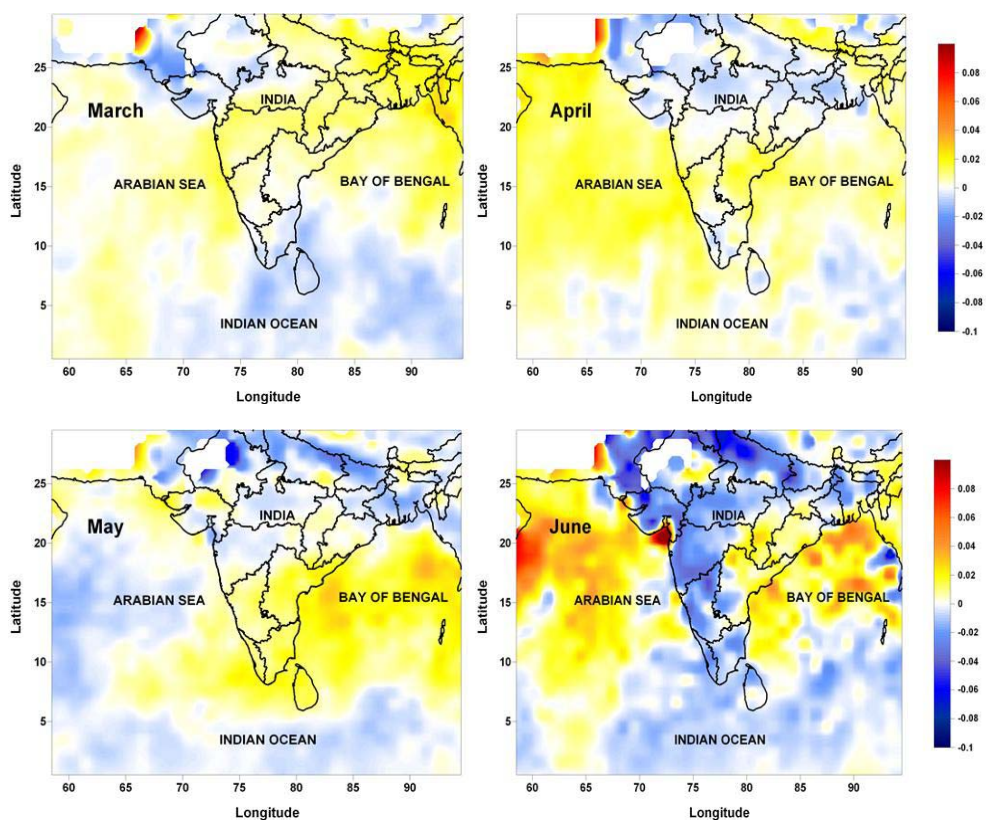

Title Page

\section{Abstract}

Introduction

Conclusions

References

Tables

Figures

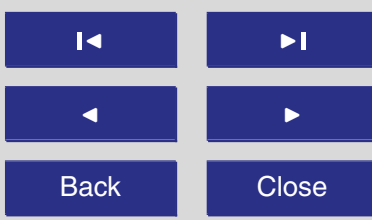

Full Screen / Esc

Printer-friendly Version

Interactive Discussion

Fig. 4a. Caption on next page. 

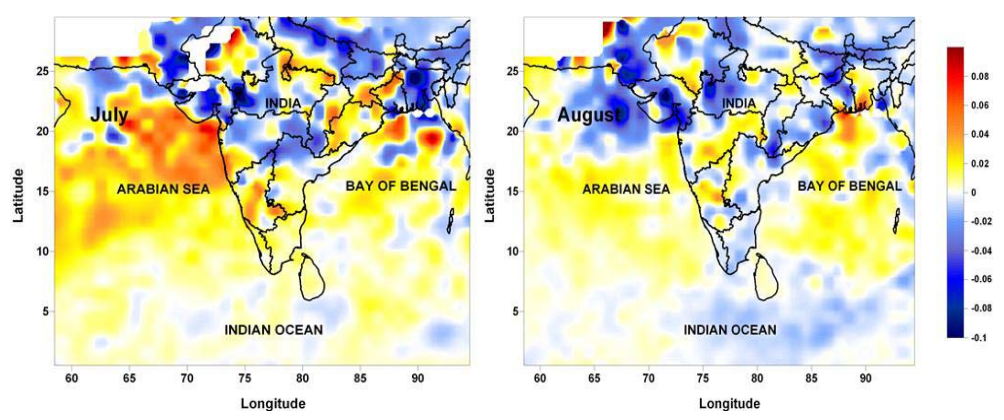

AMTD

4, 5275-5323, 2011

\section{Contrasting aerosol trends over South \\ Asia}
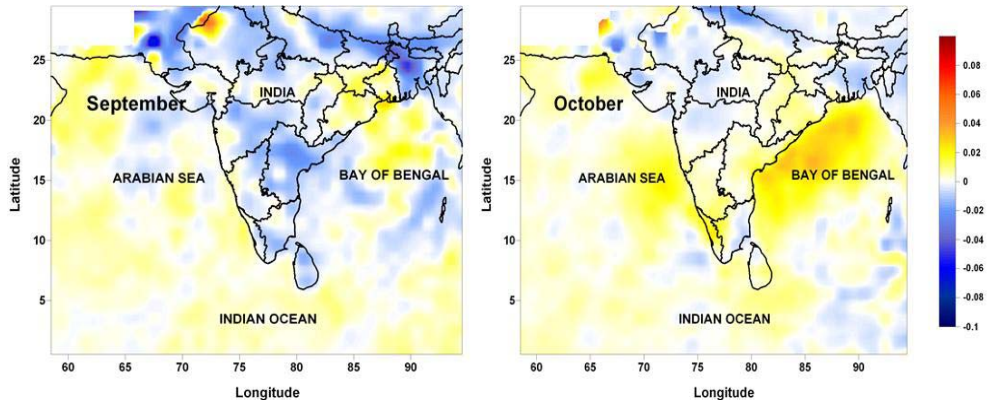

D. G. Kaskaoutis et al.
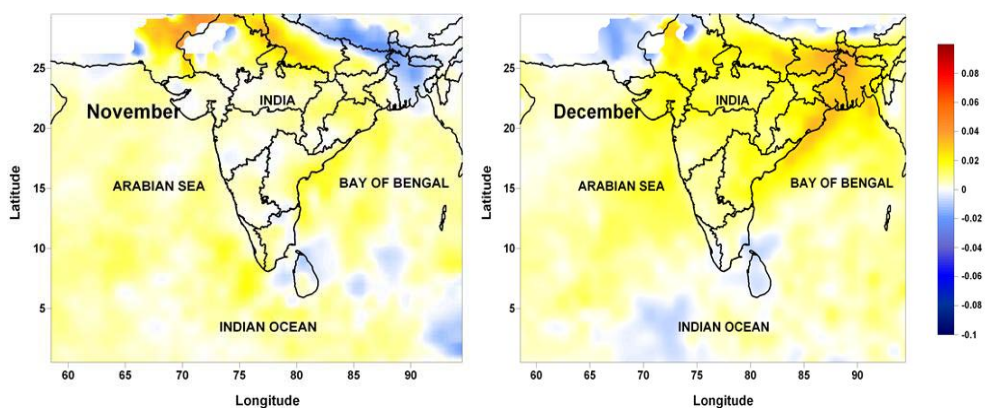

Fig. 4b. Spatial distribution of the trends in MODIS-AOD ${ }_{550}$ during the period 2000-2009. The trend values correspond to the slope of the linear regression analysis.

\section{Title Page}

\section{Abstract}

Introduction

Conclusions

References

Tables

Figures

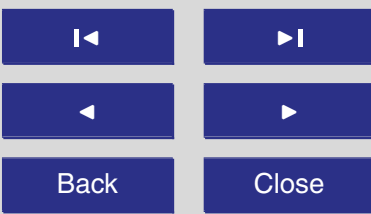

Full Screen / Esc

Printer-friendly Version

Interactive Discussion

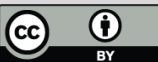


AMTD

4, 5275-5323, 2011

\section{Contrasting aerosol trends over South \\ Asia}
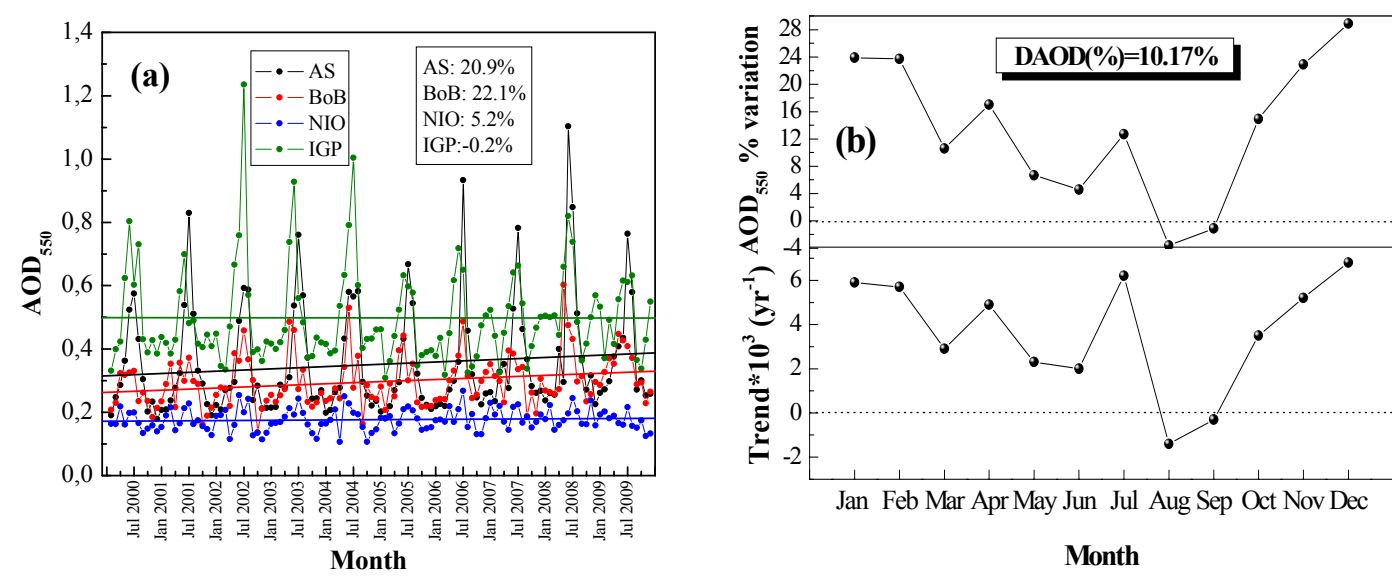

Fig. 5. Monthly-mean variation and trends for the area-averaged MODIS-AOD ${ }_{550}$ in the four sub-regions during the period 2000-2009 (a). Trend values ${ }^{*} 10^{3}$ and $\%$ variations in $\mathrm{AOD}_{550}$ calculated from the linear regression of the monthly mean $\mathrm{AOD}_{550}$ averaged over the whole south Asia during the period 2000-2009 (b).
Title Page

Abstract

Introduction

Conclusions

References

Tables

Figures

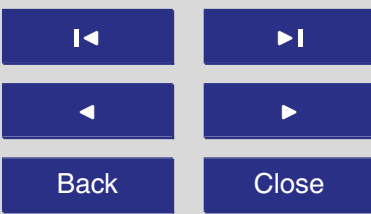

Full Screen / Esc

Printer-friendly Version

Interactive Discussion 


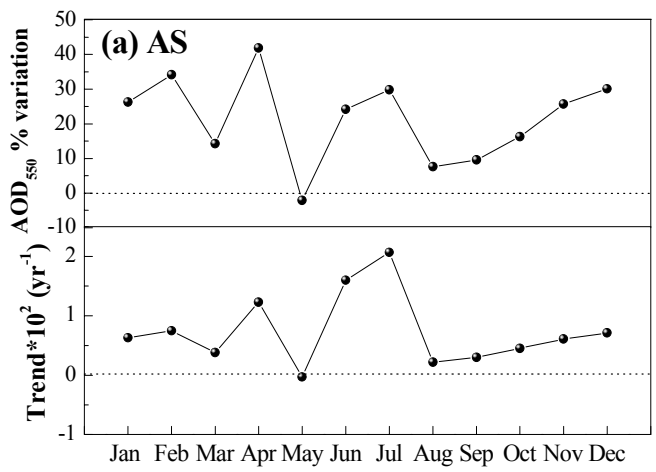

Month

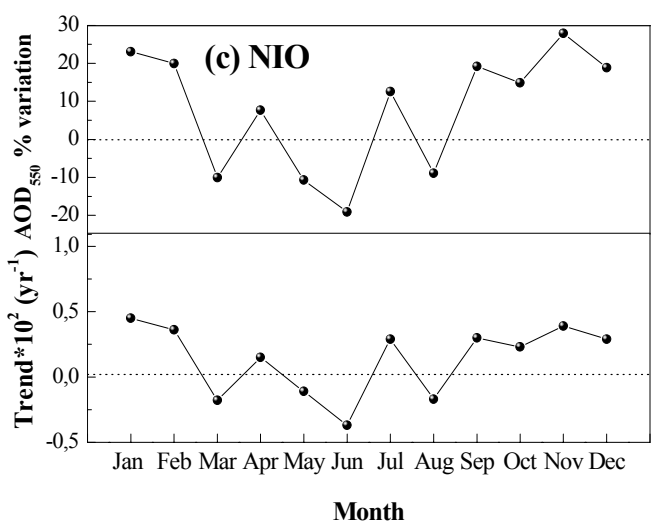

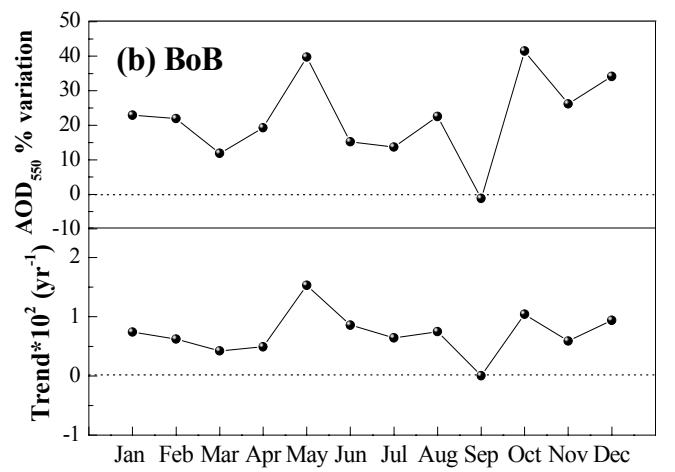

Month

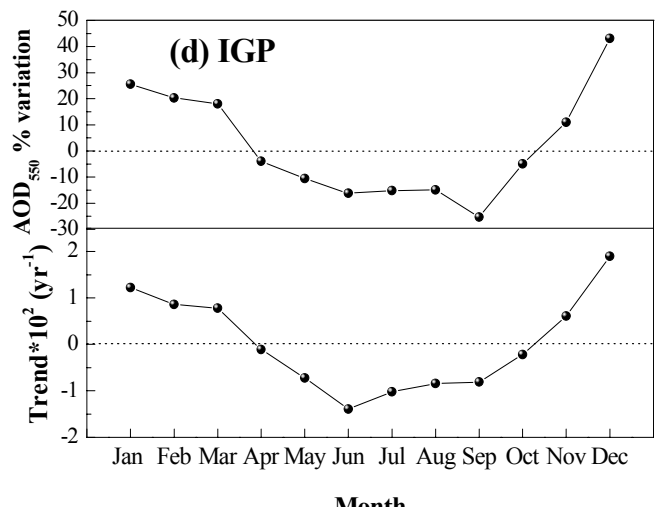

Month
AMTD

4, 5275-5323, 2011

\section{Contrasting aerosol trends over South \\ Asia}

D. G. Kaskaoutis et al.

\section{Title Page}

\section{Abstract}

Introduction

Conclusions

References

Tables

Figures

14

4

Back

Close

\section{Full Screen / Esc}

Printer-friendly Version

Interactive Discussion

Fig. 6. Trend values ${ }^{*} 10^{2}$ and $\%$ variations in the monthly mean MODIS-AOD $D_{550}$ averaged over (a) AS, (b) BoB, (c) NIO and (d) IGP in the period 2000-2009. 

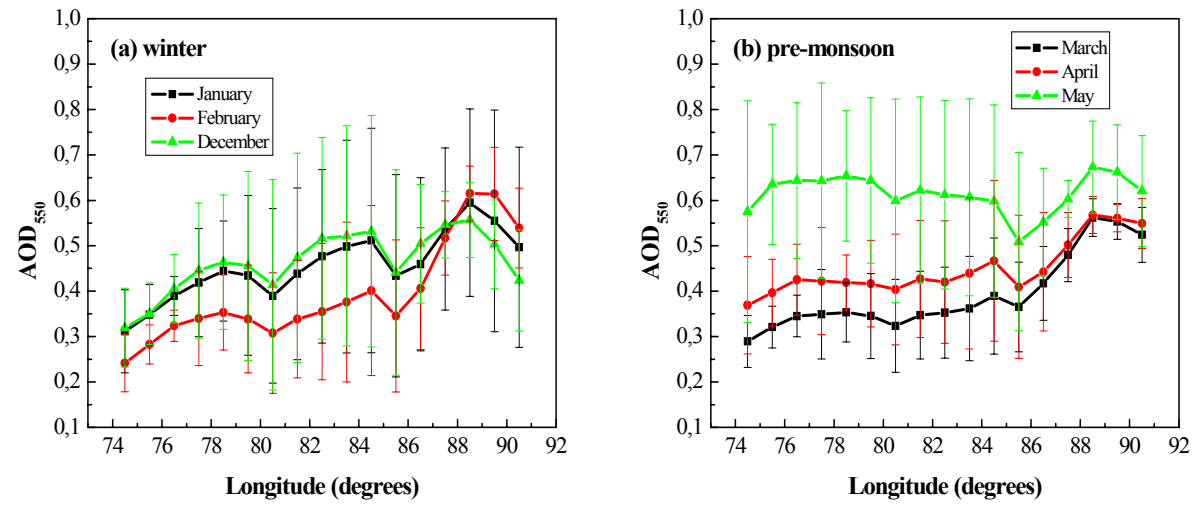

AMTD

4, 5275-5323, 2011

\section{Contrasting aerosol trends over South \\ Asia}

D. G. Kaskaoutis et al.
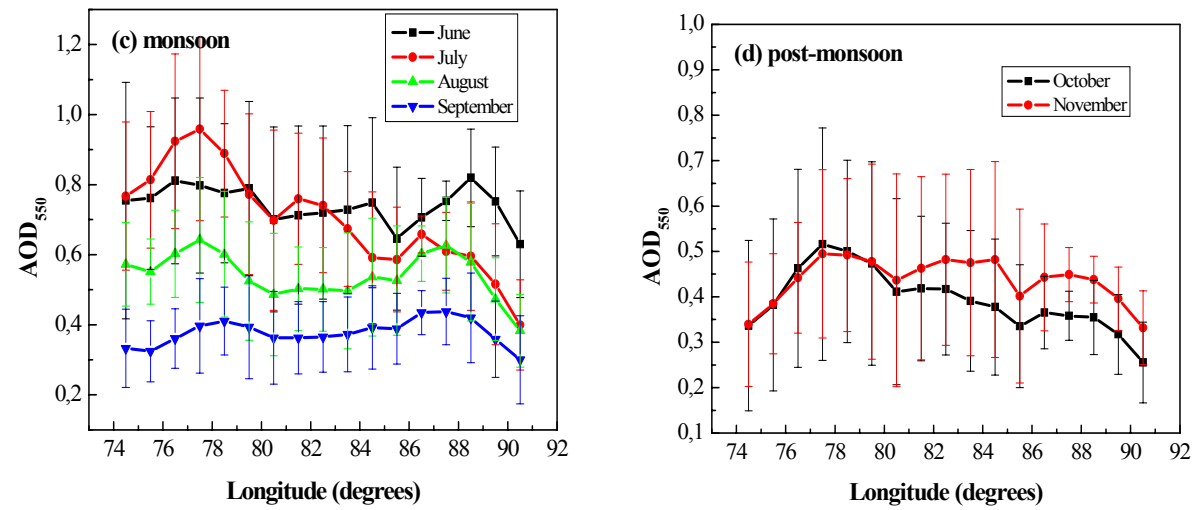

Title Page

Abstract

Introduction

Conclusions

References

Tables

Figures

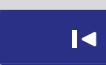

14

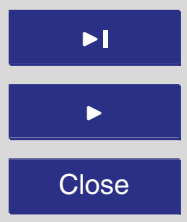

Back

Close

\section{Full Screen / Esc}

Printer-friendly Version

Fig. 7. Monthly mean longitudinal variation of the MODIS-AOD ${ }_{550}$ over IGP during the period 2000-2009. The vertical bars express one standard deviation from the latitudinal mean value. 

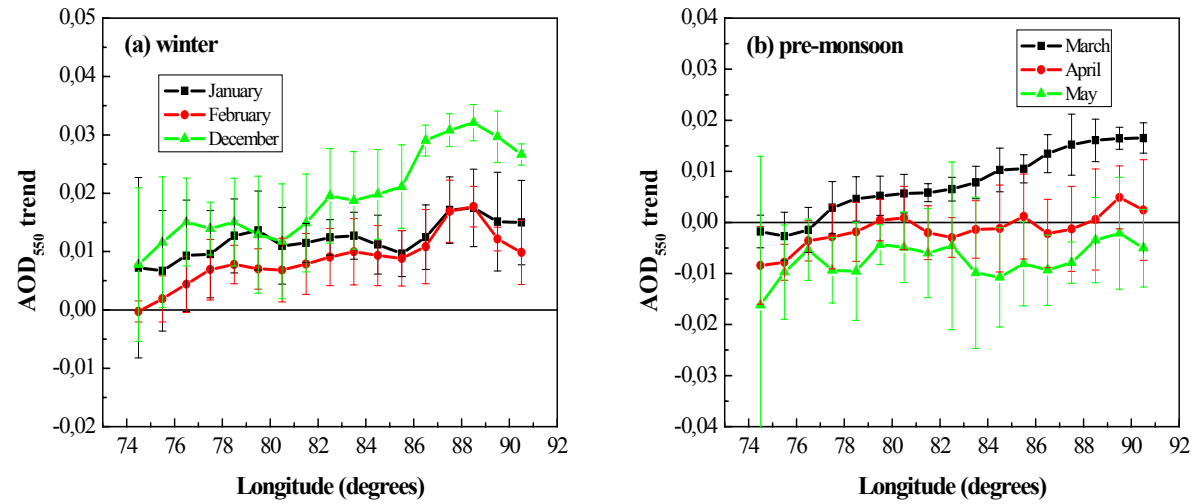

AMTD

4, 5275-5323, 2011

\section{Contrasting aerosol trends over South \\ Asia}

D. G. Kaskaoutis et al.
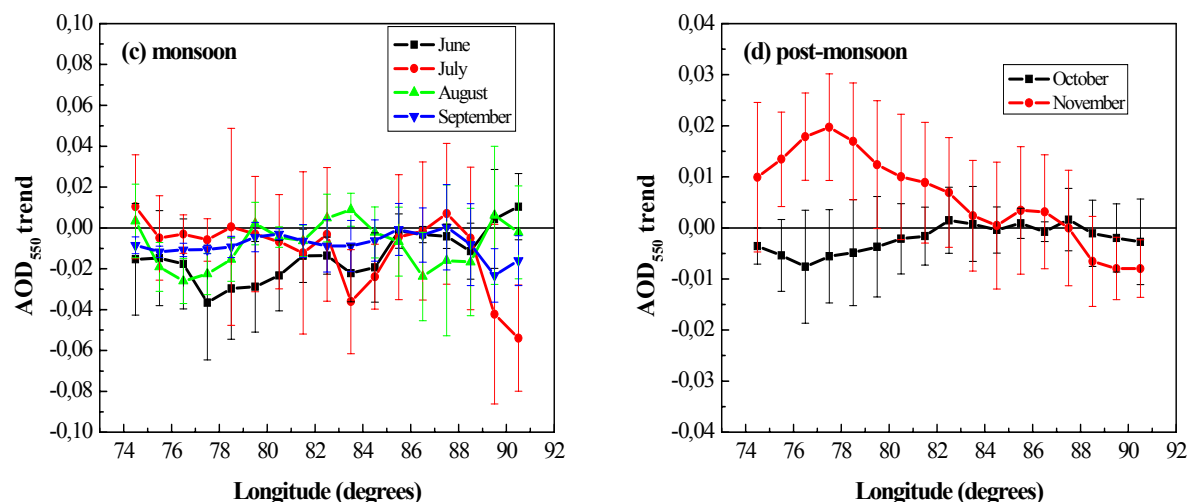

\section{Title Page}

Abstract

Introduction

Conclusions

References

Tables

Figures

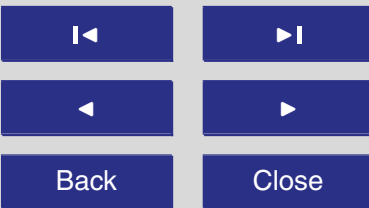

Full Screen / Esc

Fig. 8. Monthly mean longitudinal variation of the slope values indicating the MODIS-AOD ${ }_{550}$ trend over IGP during the period 2000-2009.

Interactive Discussion 


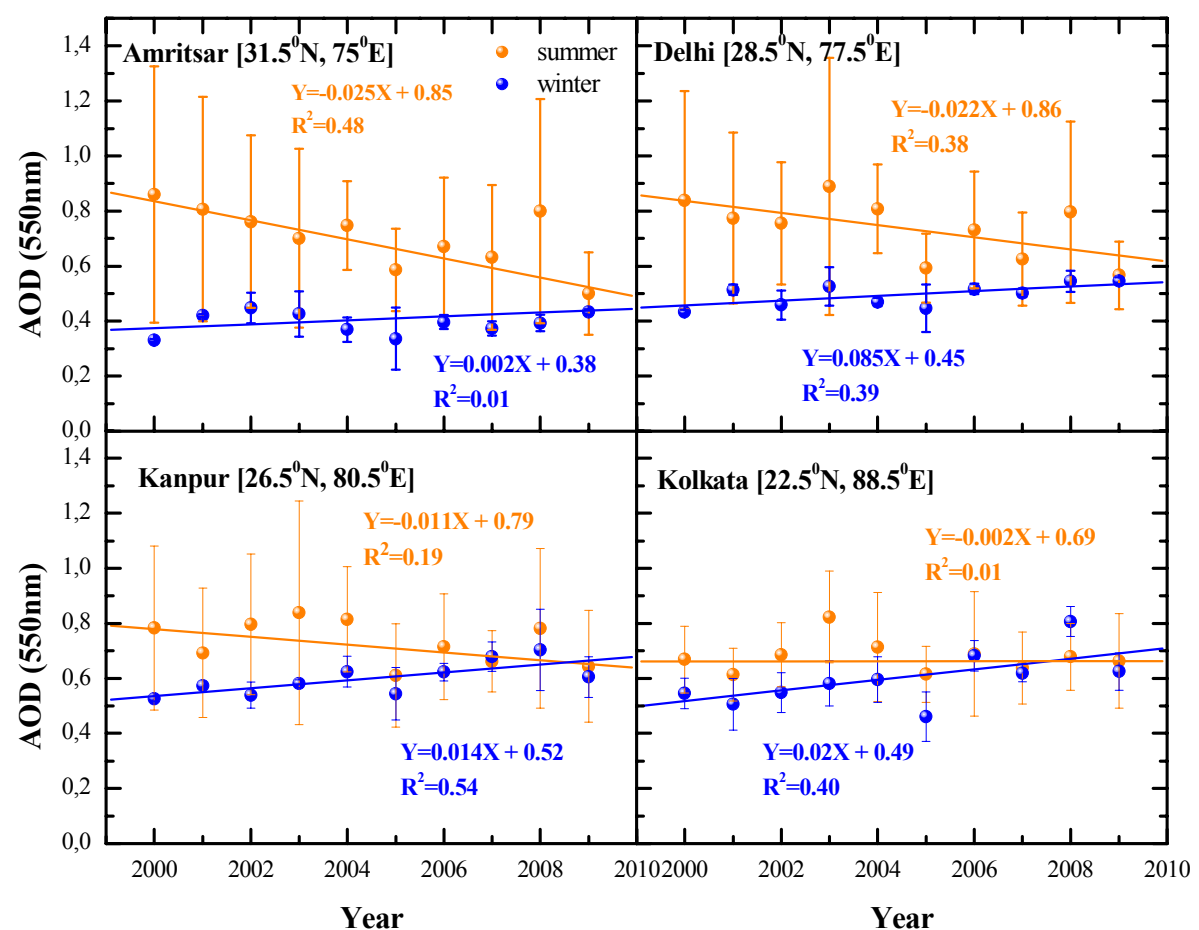

Fig. 9. Decadal variation of the yearly MODIS-AOD ${ }_{550}$ values in winter (December-January) and summer (April-June) seasons over four urban locations in IGP. The vertical bars express one standard deviation from the seasonal mean.
AMTD

4, 5275-5323, 2011

Contrasting aerosol trends over South

\section{Asia}

D. G. Kaskaoutis et al.

\section{Title Page}

Abstract

Introduction

Conclusions

References

Tables

Figures

14

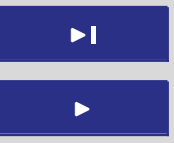

Back

Close

\section{Full Screen / Esc}

Printer-friendly Version

Interactive Discussion 


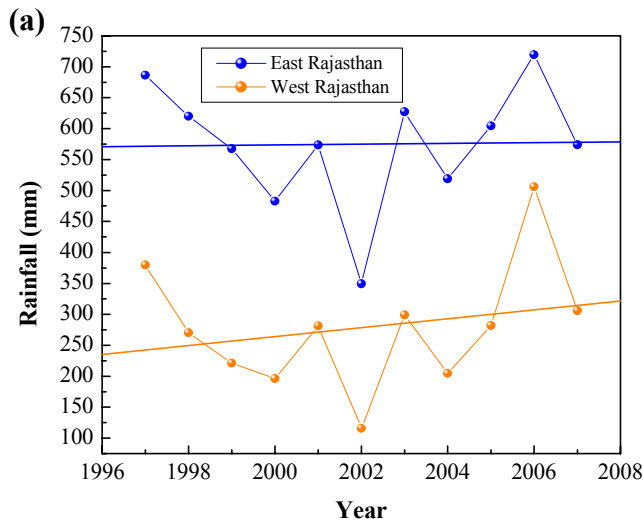

AMTD

4, 5275-5323, 2011

\section{Contrasting aerosol trends over South \\ Asia}

D. G. Kaskaoutis et al.

\section{Title Page}

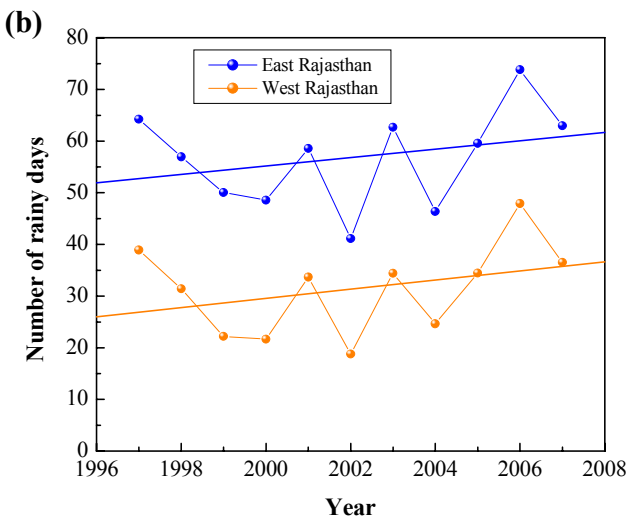

Abstract

Introduction

Conclusions

References

Tables

Figures

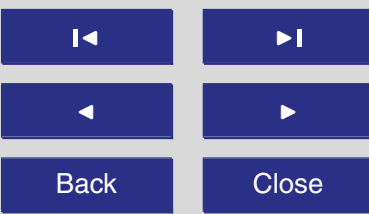

Full Screen / Esc

Fig. 10. Variation in the rainfall amount (a) and total number of rainy days (b) over east and west Rajsthan during the period April-September for the years 1997-2007. Data obtained from IMD (see text for details).

Printer-friendly Version

Interactive Discussion

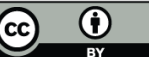


AMTD

4, 5275-5323, 2011

\section{Contrasting aerosol trends over South \\ Asia}

D. G. Kaskaoutis et al.

\section{Title Page}

Abstract

Introduction

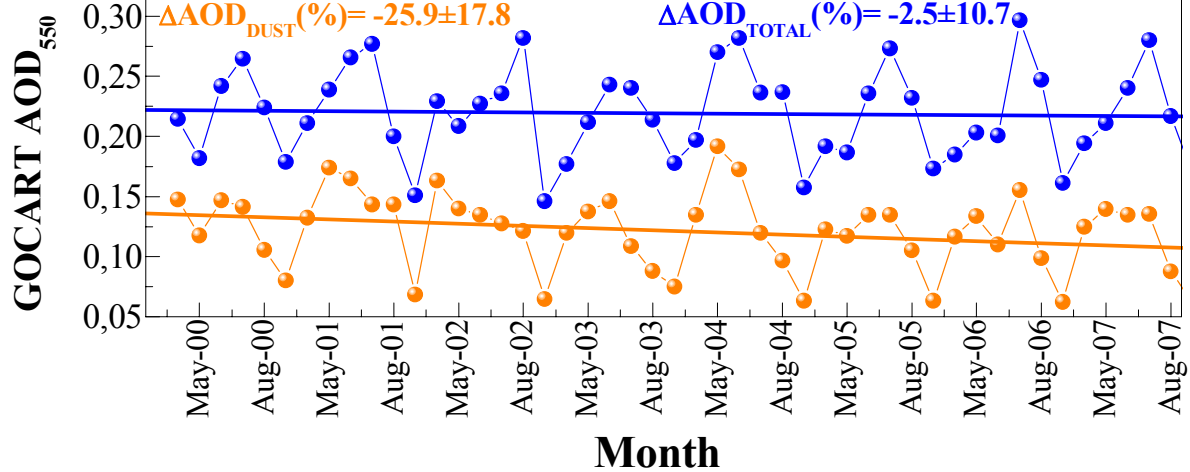

Fig. 11. Monthly variation and linear regression trends for total and dust $A O D_{550}$ (lower panel) and for dust contribution (\%) in the total $\mathrm{AOD}_{550}$ (upper panel) via GOCART simulations over south Asia for April-September in the period 2000-2007. 

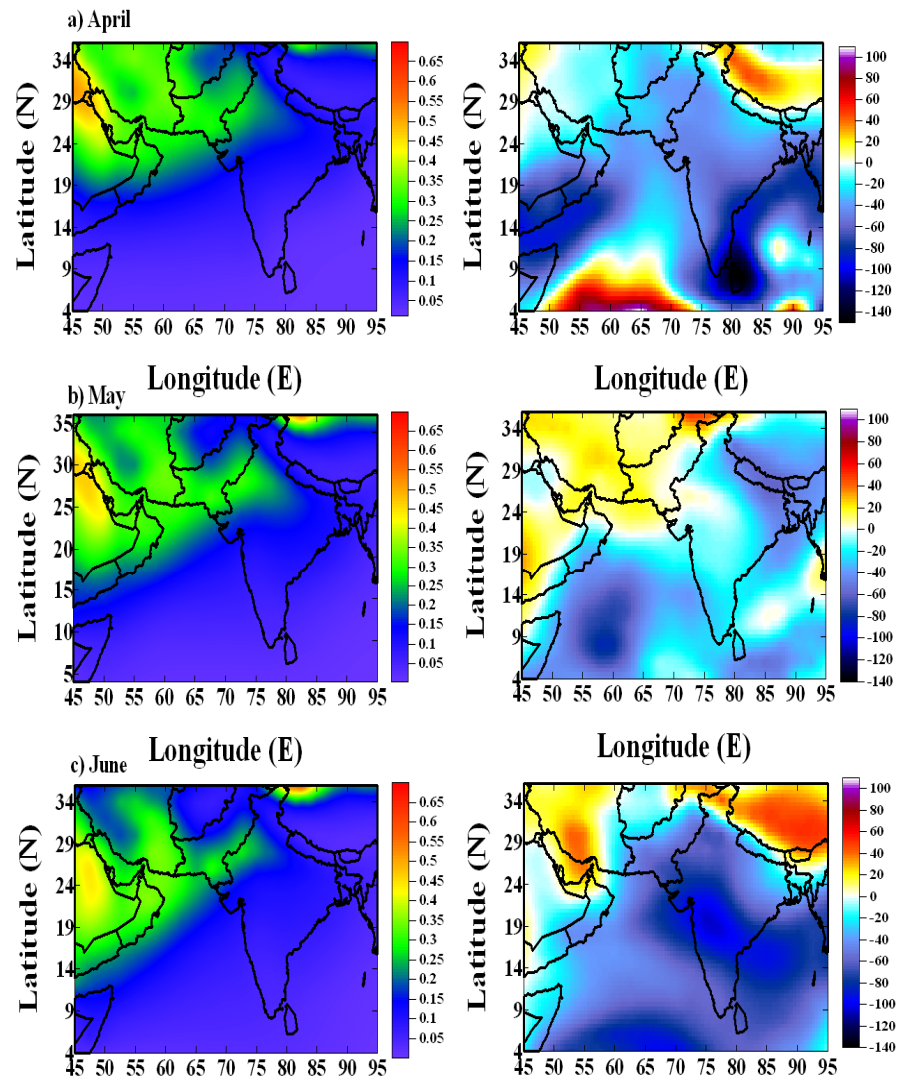

Longitude(E)
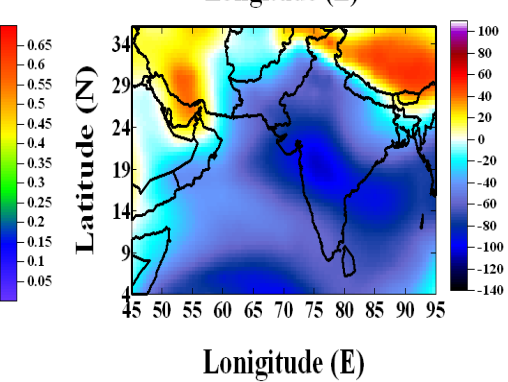

Fig. 12a. Caption on next page.

AMTD

4, 5275-5323, 2011

Contrasting aerosol trends over South

\section{Asia}

D. G. Kaskaoutis et al.

\section{Title Page}

\section{Abstract}

Introduction

Conclusions

References

Tables

Figures
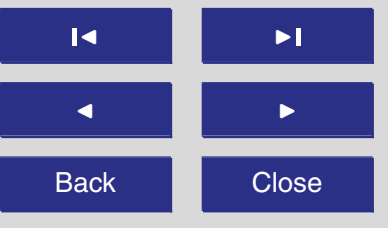

Back

Close

\section{Full Screen / Esc}

Printer-friendly Version

Interactive Discussion

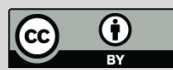




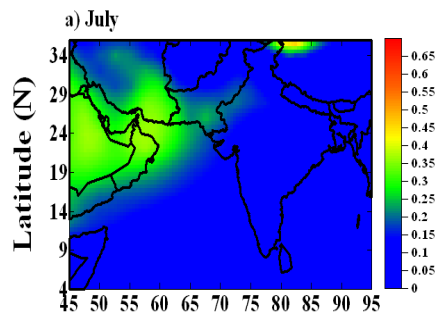

Longitude (E)

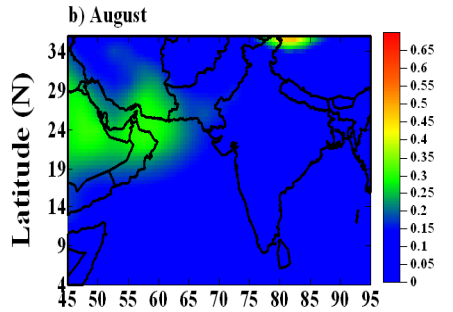

Longitude (E)

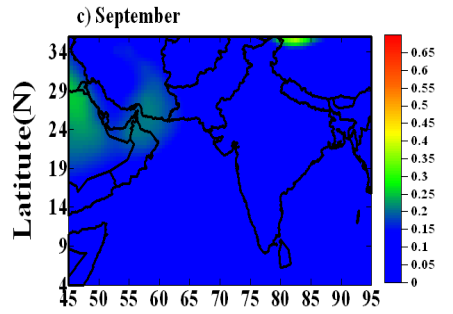

Longitude (E)
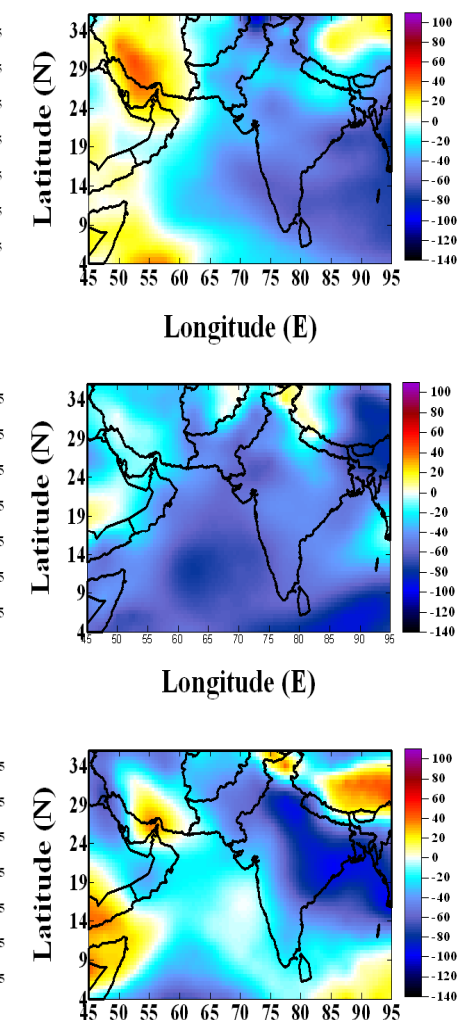

Longitude(E)

Fig. 12b. Mean values (left column) and \% variation (right column) of the dust $A O D_{550}$ over south Asia during April-September in the period 2000-2007 according to GOCART simulations.

\section{AMTD}

4, 5275-5323, 2011

Contrasting aerosol trends over South

\section{Asia}

D. G. Kaskaoutis et al.

\section{Title Page}

\section{Abstract}

Introduction

Conclusions

References

Tables

Figures

14

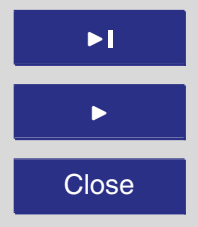

Back

Close

\section{Full Screen / Esc}

Printer-friendly Version

Interactive Discussion 

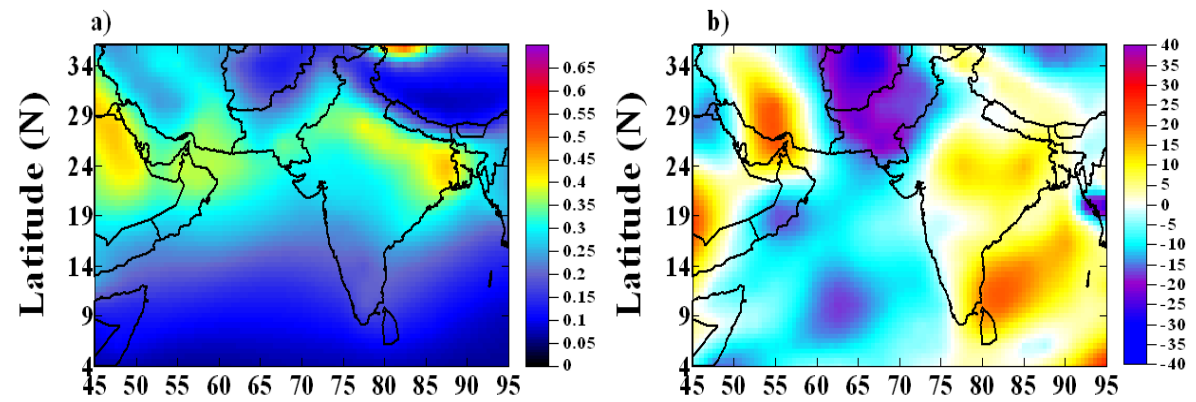

Longitude (E)

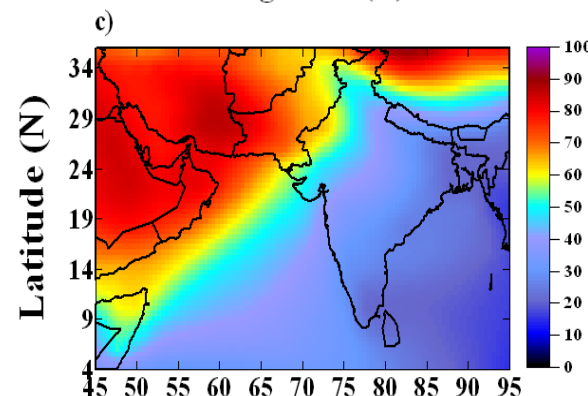

Longitude (E)

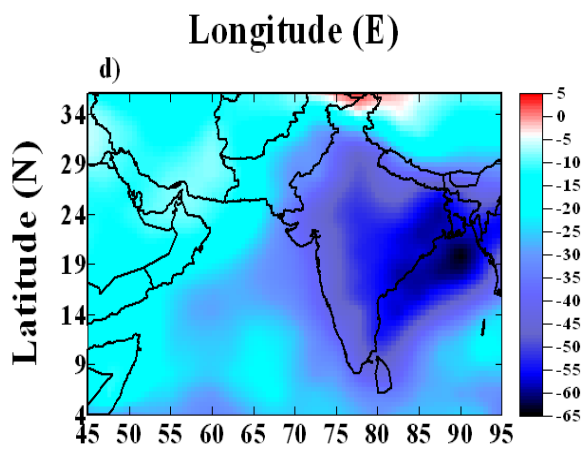

Longitude (E)

Fig. 13. Mean values and \% variation for the total $A O D_{550}((\mathbf{a})$, (b), respectively) and for the dust contribution to the total $\mathrm{AOD}_{550}$ ((c), (d), respectively) over south Asia during April-September in the period 2000-2007 according to GOCART simulations.

AMTD

4, 5275-5323, 2011

\section{Contrasting aerosol trends over South Asia}

D. G. Kaskaoutis et al.

\section{Title Page}

\section{Abstract}

Introduction

Conclusions

Tables

References

Figures

14

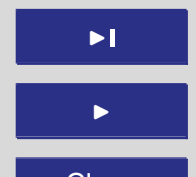

Back

Close

\section{Full Screen / Esc}

Printer-friendly Version

Interactive Discussion 